\title{
The Dominican Robert Kilwardby (ca. 1215-1279) as schoolman and ecclesiastical official
}

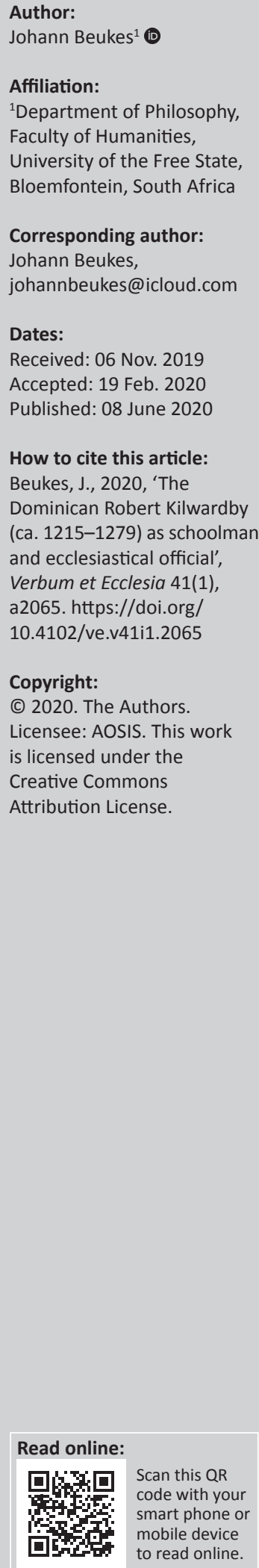

This article, by reworking the most recent specialist contributions, presents a fresh overview of the scholastic and ecclesiastical contributions of the Oxford Dominican Robert Kilwardby (ca. 1215-1279). After highlighting the current research problem of the 'canon' in Medieval philosophy, the article turns to Kilwardby as a positive example of a 'non-canonised' thinker from the high Middle Ages - one who is thus thoroughly researched in a specialised or niche compartment, but who remains mostly unacknowledged in mainstream or 'canonised' Medieval philosophy. The article thus reappraises Kilwardby intending to accentuate his scholastic and ecclesiastical contributions beyond the confines of a particular niche. Kilwardby's often provocative combination of Aristotelian natural philosophy and Augustinianism as a schoolman, and his central yet problematic role in the Paris-Oxford condemnations of 1277 as an ecclesiastical official, are henceforth reappraised.

Intradisciplinary/interdisciplinary implications: As a millennium-long discourse, Medieval philosophy functions in a Venn diagrammatical relationship with Medieval history, Church history, patristics and philosophy of religion. Whenever 'mainstream' or 'canonised' Medieval philosophy is impacted from the niche research, it may well have implications that these closely related disciplines could take note of. Such is the case in this 'hourglass' reappraisal of life and work of Robert Kilwardby as a scholastic thinker and an ecclesiastical official.

Keywords: Aristotelian natural philosophy; Augustinian influence; Brill Publishing, Leiden; A. Broadie; 'hourglass research'; intentionalism; H. Lagerlund; A. Maierù; Paris-Oxford condemnations of 1277 .

\section{Robert Kilwardby and the problem of 'canon' in Medieval philosophy}

This reappraisal ${ }^{1}$ of scholastic and ecclesiastical contributions of the Oxford Dominican Robert Kilwardby, O.P. (ca. 1215-1279) could be read against the background of a progressive research challenge in Medieval philosophy, namely, the re-engagement of many 'non-canonised' thinkers from this millennium-long period in the Western history of ideas. Research in Medieval philosophy as a philosophical and theological discipline (with reference to its overlapping relation to philosophy of religion and ecclesiastical history) is currently being confronted by three subjectinternal problems in particular: the calibration of internal periodisation, the presentation of a single register and the problem of 'canon' in Medieval philosophy. Kilwardby's research as such is affected by the last issue. However, the two aforementioned problems should be addressed here as well, even if only briefly.

The problem of the calibration of Medieval philosophy departs from the following key question: where does Medieval philosophy begin (and end); therefore, which thinkers should be included in (and which excluded from) the discipline? This is a crucial question because it determines which philosophers on the margins of historical spectrum (with Neoplatonism on the patristic left and Italian Renaissance on the pre-modern right) belong in the corpus of Medieval philosophy. Because the development of Neoplatonism and late-patristics towards the Middle Ages was slow and gradual, Medieval philosophy is sometimes dated as far back and as early as Plotinus (ca. 204-270) and Porphyreus (ca. 234-305), whilst it is often dated forward and as late as the onset of the Carolingian Renaissance (ca. 742), or at least from Boethius (ca. 480-524) onwards, which, of course, certainly excludes Augustine (354-430) from the corpus. Augustine is the pivotal figure in this periodisation issue, because it is his position which is always in dispute in the Medieval encyclopedia,

1.The objective of this article was to logically and systematically disseminate the most recent outputs in Kilwardby research, with specific reference to the philosophical exegesis of relevant and extant primary texts. The article is descriptive-analytical in its provision of an accessible overview of the contextual socio-intellectual history and synthetical in its aim to coherently integrate readings of primary texts and the most recent secondary texts. 
being either the 'first Medieval philosopher' (if the argument [Beukes 2020a:1.1] that the first successful invasion of Rome in 410 designates the onset of the Middle Ages is accepted), or the vital interrelating figure from antiquity to the Middle Ages (Beukes 2012:2352). Currently, there is no clear consensus in Medieval research about Augustine's position, either in or out of the Medieval corpus. The same lack of consensus is apparent in the closure of the corpus and the transition towards the Italian Renaissance: if Nicholas of Cusa (1401-1464; Beukes 2018d:1) is considered to be the last Medieval and first Renaissance philosopher' or perhaps the 'gatekeeper of modernity' (Gilson 1940:404), a discursive choice is thereby constituted, which always will have to be tended to anew. In dealing with methodological problems in the discipline, the author has addressed this problem thoroughly Beukes (2012:1-3; 2018a:1-2; 2018c:503-505; 2018d:610) ${ }^{1}$; however, no progress has yet been made on the possible calibration or standardisation of the dating and internal periodisation of Medieval philosophy: volatility is still exultant, and Medieval philosophers are still being arbitrarily included and excluded from the corpus. ${ }^{2}$

The second research problem in Medieval philosophy is determined by what could be labelled as a 'latent Orientalism' in the discipline. Medieval philosophy is as much Occidental as it is Oriental, as much 'West' as it is 'East' and as much Latin as it is Arabic-Jewish; yet, this embracing observation is (still) absent in by far the majority of introductions to and standardised textbooks of Medieval philosophy. The Arabic and Jewish thinkers are normally sidestepped so that the homogenised index conventionally moves straight from Eriugena (815-877) to Anselm (1033-1109). Even if the reader is fortunate, only the most consequential thinkers from the Arabic-Jewish circles since Alkindi (Anno Hegiraed. ca. 256, CE ca. 801-870) are included: Ibn Sina (Avicenna, AH370AH428, 980-1037), Ibn Rushd (Averroes, ca. AH 520-595, ca. 1126-1198) and Moses Maimonides (1138-1204). This tendency in the discipline indicates an underlying Orientalism, meaning the discursive postulation of an 'Eastern other' with the subtle intent to alleviate the notion of a 'Western self'; in other words, this Orientalism points towards the apparent spontaneous acceptance of a disparity between a superior Western self and an inferior Eastern other. Very few modern introductions to philosophy for the period 410 and 1464 have paid attention to this serious methodological issue: 'East' evidently belongs

2.In a philosophical discipline, which is otherwise notoriously technical and intensely preoccupied with precision, it is, on the one hand, inexplicable that the dating and internal periodisation of Medieval philosophy are generally dealt with such a laissez-faire approach. The author's suggestion for calibration and internal laissez-faire approach. The author's suggestion for calibration and internal six-part scheme Beukes (2011:1544; 2018a:1; 2020a:5): The post-Roman period six-part scheme Beukes (2011:1544; 2018a:1; 2020a:5): The post-Roman period
(5th to 7th centuries [410 \{Alaric I and the first successful barbaric invasion of Rome\} to 668 \{d. Constans II\}], with Augustine [354-430] and Boethius [480-524] as the leading philosophical exponents) (2) The Carolingian period (8th and 9th centuries [742 \{b. Charles I\} to 877 \{d. Eriugena\}], with Alcuin [730-804] and Eriugena [815-877] as the leading Latin-West exponents of the Carolingian Renaissance, vis-à-vis the rise of Arabic philosophy in Baghdad and Andalusia Spain (3) The post-Carolingian period (9th to 11th centuries [877 \{d. Eriugena\} to 1088 \{onset of crusades and the rise of first universities\}], with Anselm [1033-1109] and Abelard [1079-1142] as the most influential amongst the Latin-West thinkers who Abelar ll profited from the robilitation of antiquity in the Carolingian Renkissance) (4) The early scholastic period (12th to 13th centuries [1088 ffounding of the (4) The early scholastic period (12th to 13th centuries [1088 ffounding of the University of Bologna, the first European university\} to 1225 \{b. Aquinas\}]) (5) The \{d. Ockhastic period (13th to 14 h centuries [1225 (b. Aquinas\} to 1349 \{d. Ockham\}, with Aquinas, Duns Scotus and Ockham as the most influential amongst the high scholastics]) (6) The post-scholastic period (14th to 15th centuries [1349\{d. Ockham\} to 1464 \{d. Cusa\}]). to 'East', with all the pejorative undertones and editorial decisions, inclusions and exclusions, which characterise receptions from 'West to East' in modern commentaries and introductions. Should a 21st-century reappraisal of Medieval intellectual history not at least concede that the first pursuit in antagonising such an Orientalism should come forth from precisely acknowledging Western prejudices regarding the eastern register? Does the Middle Ages not, in fact, constitute a discursive space in terms of text, geography and translation, where it should become clear that the Greek in Persia is as much lost as the Arabic philosopher in Athens? Should there in 21st-century receptions not be a more dedicated effort to juxtapose divergent Medieval traditions - historically, ethnically, spiritually and linguistically - rather than subordinating one or more of these trajectories in terms of geographical and modernist Vorhabe? When one subtly elaborates on the 'Arabic trajectories in Medieval philosophy' with the explicit intent to soften the hard lines between the two registers, it indeed is profitable to unmask the persistent socio-historical prejudice in the Western register, working towards a suppler hermeneutical attitude to all the texts at hand; for what they are and what they represent (Beukes 2018a:539-540, 2018d:601). The undeniable fact is that at least 150 years of the history of ideas are circumvented by this very old and established prejudice - a history of ideas characterised precisely by the intellectual labour of a significant number of Arabic and Jewish thinkers. It has become progressively problematic to index the Arabic thinkers of Middle Ages in adjacent disciplines such as 'Philosophy of Islam', whilst the register of Medieval philosophy is then automatically composed, with few exceptions, by thinkers from the Latin West. Of course, the specialised exegeses of these Arabic thinkers still belong to sub-disciplines that could linguistically analyse the Arabic texts as such; yet, these thinkers should be far more rigorously, and less specialised, presented in mainstream introductions to Medieval philosophy than is even still currently the case. The established (Western) register of Medieval philosophy should endeavour to introduce the vast index ${ }^{3}$ of Medieval Arabic philosophers, which are thus

3.lbn al-Muqaffa (d. AH 139/757); Masha Allah (d. ca. AH 200/815); Ibn al-Bitriq (fl ca. AH 200/815); Abu al-Hudhayl (d. ca. AH 226/840); Al-Nazzam (d. AH 225/840); Al-Himsi, Ibn Naima (fl. ca. AH 215/830); Al-Kindi (Alkindi) (d. AH 256/870); Ibn Ishaq Hunayn (Hunein; loannitius) (d. ca. AH 260/873); Al-Balkhi, Abumasha (Albumasar) (d. AH 272/886); Ibn Qurra, Thabit (Thebit) (d. AH 288/901); Ibn Haylan, Yuhanna (Heilan) (d. AH 297/910) Ibn Lea, Qusta (Constabulus) (ca. AH 205/820-300/912); Al-Jubbai, Abu Ali (d. AH 303/915-16); Al-Razi, Abu Bakr (Alrazi) (d. AH 313/925); Al-Balkhi, Abu al-Qasim (d. AH 319/931); Al-Jubbai, Abu Hashim (d. AH 321/933); Abu Hatim (d. AH 322/934); Abu Zayd (d. AH 322/934); Al-Ashari, Abu al-Hasan (d. AH 324/935); Ibn Yunus, Abu Bishr Matta (Junus) (d. Al-Ashari, Abu al-Hasan (d. AH 324/935); Ibn Yunus, Abu Bishr Matta (Junus) (d. AH328/940); Israeli, Isaac (ca. 855-955); Gaon, Saadiah (882-942); Al-Nasafi (Alnasafi) (d. AH332/943); Al-Farabi (Alfarabi) (d. ca. AH 339/950); Al-Sijistani, Abu Yaqub (d. ca. AH 358/971); Ibn Adi, Yahya (d. AH363/974); Al-Sirafi, Abu Said (Alsirafi) (d. AH369/979); Al-Sijistani, Abu Sulayman (d. ca. AH 375/985); AlAndalusi, lbn Juljul (Gilgi) (d. ca. AH 377/987); Al-Amiri (Alamiri) (d. AH381/991); Ibn al-Nadim (d. ca. AH 388/998); Ibn Zura, Abu Ali Isa (d. AH398/1008); Al-Kirmani, Hamid al-Din (Alkirmani) (d. ca. AH 412/1021); Abd al-Jabbar (d. AH415/1025); Ibn Miskawayh (d. AH421/1030); Ibn al-Haytham (Alhacen) (d. ca. AH 432/1040); Ibn Sina (Avicenna) (AH370/980-428/1037); Ibn al-Tayyib, Abu al-Faraj (d. AH434/1043); Al-Biruni (Albiruni) (d. 440/1048); Ibn Gabirol, Solomon (Avicebron) (1021-1070); Ibn Hazm (d. AH456/1064); Ibn Marzuban, Bahmanyar (d. AH459/1066); Ibn Said al-Andalusi, Abu al-Qasim Said (Andalusi) (d. AH462/1070); Ibn Mattawayh (d. AH 469/1076-7); Nasiri Khusraw (d. ca. AH 470/1077); Al-Shirazi, al-Muayyad (Alcirazi) (d. AH 470/1077); Al-Juwayni, Imam al-Haramayn (Haramein (d. AH 478/1085); Al-Lawkari, Abu al-Ábbas (fl. AH 503/1109-10); Al-Ghazali, Abu (d. AH 478/1085); Al-Lawkari, Abu al-Abbas (fl. AH 503/1109-10); Al-Ghazali, Abu Hamid (Algazali) (AH 450/1058-505/1111); Al-Nasafi, Abu al-Muin (d. AH 508/1114-15); Ibn Bajja (Avempace) (d. AH 533/1139); Halevi, Judah (d. AH 1141); Al-Baghdadi, Abu al-Barakat (d. AH 560/1165); Ibn Daud, Abraham (ca. 1110-1180); Ibn Tufail (Abubecar) (d. AH 581/1186); Suhrawardi (AH 549/1154-587/1191); Ib Rushd (Averroes) (AH 520/1126-595/1198); Al-Bitruji (fl. ca. AH 600/1204); Moses Maimonides (1135-1204); Al-Razi, Fakhr al-Din (d. AH 606/1210); Al-Baghdadi, Abd al-Latif (d. AH 628/1231); Ibn Arabi (AH 560/1165-638/1240); Ibn Yunus, 
effectively researched in specialised linguistic sub-disciplines to expand that register and to work towards a single register in the discipline. Without this expansion, the Western register remains restricted, and the discursive integrity of the register is, in the author's opinion, always under suspicion. That is why Copleston (1993:186) considered it obligatory to pose this fundamental question in his celebrated introduction (first edition 1950, second edition 1972:104-125): Why should Islamic philosophy be discussed in introductions to Western Medieval philosophy? Walzer (1967:643-652) was the first scholar to meticulously answer this question; however, it still took almost three decades for hyper-inclusive introductions and readers (similar to those of Bosley \& Tweedale [2004], Gracia \& Noone [2006] and Hyman, Walsh \& Williams [2010]) to methodically include Arabic thinkers in their indexes of Medieval philosophy. Yet, there is still a long way to go before parity between 'East' and 'West' and a single register in the discipline is finally established: both registers should be enriched from their specialised or niche sources but with the intention that both registers, in the end, be spontaneously recognised as, in fact, one. ${ }^{4}$

In conjunction with the above, the research problem that more directly affects Kilwardby's scholarship has to deal with the problem of the 'canon' in Medieval philosophy. Specialised or niche research in Medieval philosophy undoubtedly makes the most essential contribution to the in-depth exegesis of the Medieval corpus and enables non-specialised research (which can also be called 'introduction research's) to engage the lesser-known or completely unknown Medieval philosophers with some erudition. However, in the majority of cases, niche research is confined to the niche itself, and the outputs from niche research remains unexpanded and unexplored in the broader discipline of Medieval philosophy, and, of course, in the overall subject of philosophy itself. The severe consequence is that niche research has no impact on the established 'canon' (quotation marks henceforth omitted) of Medieval philosophy

\section{(footnote 3 continues)}

Kamal al-Din (d. AH 639/1242); Ibn al-Qifti (d. AH 646/1248); Falaquera, Shem-Tov (d. ca. 1295); Al-Abhari, Athir al-Din (d. AH 663/1264); Ibn Abi Usaybia (d. AH 668/1270); Al-Tusi, Nasiral-Din (d. AH 672/1274); Al-Katibi, Najm al-Din al-Qazwin (d. AH 675/1276); Ibn Kammuna, Sad al-Din (d. 1277); Al-Baydawi (d. ca. AH 685/1286); Al-Shahrazuri, Shams al-Din (d. ca. AH 688/1289); Albalag, Isaac (fl. 1290); Al-Shirazi, Qutbal-Din (d. AH 710/1311); Al-Hilli, al-Allama (d. AH 726/1325); Ibn Taymiyya (d. AH 728/1328); Levi ben Gersom (Gersonides) (12881344); Al-Isfahani, Mahmud (d. AH 749/1348); Al-lji (d. AH 756/1355); Ibn al-Khatib (d. AH 776/1375); Al-Taftazani, Sad al-Din (d. AH 792/1390); Ibn Khaldun (AH 732/1332-808/1406); Crescas, Hasdai (d. ca. 1411); Isfahani, Ibn Torkeh (d. ca. AH $836-7 / 1432$ ).

4. Reference can in this regard be made to Michel Foucault's involvement in the Iranian revolution of 1978-1979 (Beukes 2020h) in that Foucault's thought is relevant and valuable in the critical engagement of Orientalism in whatever form or guise, especially when it is effectively camouflaged or configurated as harmless guise, especially when it is effectively camouflaged or configurated as harmless
(as precisely is the case with the single Western register and the 'canon' in the (as precisely is the case with the
discipline of Medieval philosophy).

5.The use of the terms introduction research and niche research must be precise: the former refers to by far the most general engagement of the discipline (by lecturers and students in particular) via introductory works, companions and readers. Introduction research is thus dependent on the canon as reflected in these kinds of texts: very seldom would typical readers of these texts move beyond what is presented in them and engage niche outputs as such. Niche research, on the other hand, refers to the specialist analyses of the extant corpus of a particular thinker, hand, refers to the specialist analyses of the extant corpus of a particular thinker, or in the case of can spictur legacy, as well as the specialist engagement of a particular period or a restricted frame within a broader period. philosophy for niche researchers to work their whole career on just one or perhap two Medieval thinkers. It speaks for itself that as long as the outputs of niche research remain within the niches themselves, neither the canon nor the introduction research will be challenged or altered by it. so that the well-known and indeed famous philosophers' legacies remain intact and undisturbed in mainstream Medieval philosophy, whilst the lesser-known and wholly unknown thinkers are rarely enabled to penetrate the canon. The niches are generally inaccessible outside of specialist abilities and interests and are seemingly content to deliver outputs for the sake of niches themselves, with the consequence that researchers within a particular niche only communicate with each other, and do not seem interested whether the niche is actually impacting the broader discipline. The challenge posed by the problem of the canon in Medieval philosophy is therefore to influence mainstream Medieval philosophy and to challenge its canon from within niche research as such. If this challenge is progressively met, and perhaps not in the too distant future, marginal Medieval thinkers, such as Jean Quidort, John of Salisbury and Robert Kilwardby, would be as ubiquitous as their famous kindred such as Augustine, Peter Abelard, Thomas Aquinas, Albert the Great, Bonaventure, John Duns Scotus and William of Ockham. ${ }^{6}$

Surely, one has to accept that it is not possible to present every noteworthy thinker from the Middle Ages in every introduction, companion or reader. What is to be questioned is that it is, on the one hand, the same thinkers who are continually presented as 'central' or 'crucial', and, on the other hand, the same thinkers who are over and over again excluded and understated. Canonised thinkers such as the above-mentioned Aquinas et al. hold a vast secondary literature which, in a variety of modern languages, has become effectively unsurveyable. Why these canonised thinkers are still presented with so much over-accentuation in introductions, companions and readers, may appropriately strike a critical reader as unjust towards the historical density and vastness of the Medieval epoch itself. It is certainly true that some Medieval philosophers were more consequential and influential than others: However, no Medieval thinker achieved what she/he had in isolation. It was precisely the socio-historical context, mediated by many other thinkers and contexts, preceding and contemporaneous to a particular philosopher, which enabled that philosopher to contribute with a prestige output - which is precisely the case with the canonised thinkers. The immediate question is whether that context is being assessed outside the frames of that particular niche - and the hermeneutical answer is that, in the majority of cases, it is not. Medieval philosophy's contemporary research interests should therefore progressively focus on the underpublished, marginal thinkers from the Middle Ages and there are quite a number of them if one seriously engages the archives.

6.Of course, the problem of the canon in Medieval philosophy forms part of a much larger and even more complex problem in contemporary science, namely, the problem of hyper-specialisation. It has been argued elsewhere Beukes (2020f) that this problem could be interpreted as the historical-logical consequence of that very first division of sciences, that is in the strict distinction between philosophy and theology in early scholasticism, with tempo-induced specialisation, hyper-inductive specialisation and the prioritisation of mechanical disciplines being its evident manifestations in contemporary science.

7.The following Medieval thinkers are regarded as compacted within niche domain and therefore as understated (in some cases, to the point of being completely unknown) in the broader introduction research. Some of these thinkers thus have a unknown) in the broader introduction research. Some of these thinkers thus have a whilst some are not studied even in a single or particular niche at all, and 
It is precisely the extensiveness ${ }^{8}$ of this list that constitutes the research problem. On the one hand, this list makes it imperative that niche research must somehow be opened up so that Medieval philosophy, as a truly technical and historical-philosophical discipline, could be enriched by accessible reappraisals of the many lesser-known and unknown or non-canonised thinkers from the epoch. More work must thus be conducted between niche research and introduction research to counter the effect of an inward, inaccessible and, in the end, unproductive hyperspecialisation in the discipline. 'Reappraising' or 'reworking' receptions could contribute significantly in the opening up of these hyper-specialised and often inaccessible niches, conveying the specialised outputs back to the broader discipline. This 'reappraising' or 'reworking' dynamics could

(footnote 7 continues)

consequentially remain mute in the shadows of the standardised scholastic version of the Medieval history of ideas. The Medieval Arabic and Jewish philosophers are, with few exceptions (again, Ibn Sina [Avicenna], Ibn Rushd [Averroes] and Moses Maimonides) and in terms of what was pointed out supra with reference to Orientalism and a double register, by definition marginalised in the discipline of Orientalism and a double register, by definition marginalised in the discipline of
Medieval philosophy (note that 'B2020a' refers to 'Beukes 2020a'): Alcuin of York (730-804; Beukes 2018c:505-509); Peter Damian (1007-1072; Beukes 2019f); (730-804; Beukes 2018c:505-509); Peter Damian (1007-1072; Beukes 2019f); William of Champeaux (ca. 1070-1121; Beukes 2019c:4 [fn. 4]); Hêloise d'Argenteuil (ca. 1100-1164; Beukes 2019c:7-12); Adelard of Bath (ca. 1080-1152; B2020a:3.12); Gilbert of Poitiers (1085-1154; B2020a:3.13); Peter the Venerable (ca. 1092-1156 (1098-1179; although 'marginalised' only in a relative sense, given solid feminis readings of Scivias; see Beukes 2019a:65-67); Peter Helias (ca. 1100-1166; B2020a:4.6); Richard of St Victor (d. 1173; Beukes 2020g:4); John of Salisbury (ca. 1115-1180; Beukes 2019e); Gundissalinus (ca. 1110-1190; B2020a:4.9); Alan of Lille (d. 1203; B2020a:4.11); William of Auxerre (ca. 1140-1231; B2020a:4.13); Phillip the Chancellor (Cancellarius Parisiensis; 1165-1236; B2020a:4.14); Alexander of Hales (ca. 1185-1245; B2020a:4.16): William of Auvergne (ca. 1180-1249; B2020a:4.17); John of Rochelle (ca. 1190-1245; B2020a:4.18); William of Sherwood John of Rochelle (ca. 1190-1245; B2020a:4.18); William of Sherwood (ca. 1200-1271; B2020a:4.20); Richard Fishacre (ca. 1205-1248; B2020a:4.21) Mechtild (ca. 1207-1282; Beukes 2019b); Richard Rufus of Cornwall (fl. 1231-1256 B2020a:4.23); William Arnaud (fl. 1260; B2020a:4.24); Peter Maricourt (fl. 1267; B2020a:4.25); Hadewijch of Antwerp (fl. 1240; Beukes 2020g); Ulrich von Strassbur (ca. 1220-1277; B2020a:4.32); John Peckham (ca. 1230-1292; B2020a:5.2); Boethius of Dacia (fl. 1270-1280; B2020a:5.3); William of Ware (fl. 1290; B2020a:5.4); James of Metz (fl. 1300; B2020a:5.5); Thomas of Erfurt (fl. 1300; B2020a:5.6); Martin of Dacia (d. 1304; B2020a:5.7); Peter of Auvergne (d. 1304; B2020a:5.8); John of Paris (Quidort, ca. 1255-1306; Beukes 2019d); Roger Marston (ca. 1235-1303; B2020a:5.11); Arnauld of Villanova (1238-1311; B2020a:5.12); Siger of Brabant (ca. 1240-1282; B2020a:5.13); Matthew Aquasparta (ca. 1240-1302; B2020a:5.14); Peter Olivi (ca. 1248-1298; B2020a:5.16); Richard of Middleton (ca. 1249-1302; B2020a:5.17); Godfrey Fontibus (ca. 1250-1307; B2020a:5.18); Meister Dietrich (ca. 1250-1310; B2020a:5.19); Marguerite Porete (ca. 1250-1310; Beukes 2020c); Thomas of Sutton (ca. 1250-1315; B2020a:5.21): Hervaeus Natalis (1250-1323; B2020a:5.21): James of Viterbo (ca 1255-1307; B2020a.5.23). Simon of Faversham B2020a:5.21); James of Viterbo (ca. 1255-1307; B2020a:5.23); Simon of Faversham (ca. 1260-1306; B2020a:5.24); Vitalis du Four (ca. 1260-1327; B2020a:5.25); Thoma Wilton (fl. ca. 1312; B2020a:5.29); Gonsalvo of Spain (d. 1313; B2020a:5.30); Henry of Harclay (ca. 1270-1317; B2020a:5.31); Radulph Brito (ca. 1270-1320 B2020a:5.32); Durand of St Pourçain (1270-1334; B2020a:5.33); Walter Burley (1274-1344; B2020a.5.34), William of Alnwick (ca. 1275-1333; B2020a:5.35); Pete Aureol (1280-1322; B2020a:5.36); William Crathorn (fl. 1330; B2020a:5.37); Robert Holcot (d. 1349; B2020a:5.38); Guido Terrena (d. 1342; B2020a:5.39); Richard of Campsall (ca. 1280-1350; B2020a:5.40); Walter Chatton (ca. 1285-1343; B2020a:5.41); John of Reading (ca. 1285-1346; B2020a:5.42); John of Jandun (1285-1328; B2020a:5.43); Francis Mayronis (1288-1328; B2020a:5.44); Levi ben Gershom (Gersonides, 1288-1344; B2020a:5.45); Richard Swineshead (fl. 1340-1350; B2020a:5.46); Francis of Marchia (ca. 1290-1344; B2020a:5.47); John Baconthorpe (ca. 1290-1345; B2020a:5.48); John of Mirecourt (fl. ca. 1345; B2020a:5.49); Thomas Bradwardine (1295-1349; B2020a:6.2); Jan van Ruusbroec (1293-1381: Beukes 2020d). Peter Ceffons (fl. ca. 1349. B2020a:6.5). Richard (1293-1 (f1; 1350-1373. B2020a:6.6); Nichons (Autr. 1349; B2020a:6.5); Richard Brinkley (Al. $130-1373$; B2O2Oa:6.6); Nicholas of Autrecourt (ca. 1300-1350); Rober of Halifax (ca. 1300-1350; B2020a:6.8); Landulph Caracciolo (d. 1351; B2020a:6.9); Gregory Rimini (ca. 1300-1358; B2020a:6.10); Richard Fitzralph (ca. 1300-1360; B2020a:6.11); Berthold of Moosburg (ca. 1300-1361; B2020a:6.12); Adam Wodeham (d. 1358, B2020a:6.13); Richard Kilvington (1302-1361; B2020a:6.14); John Dumbleton (ca. 1310-1349; B2020a:6.15); Ralph Strode (fl. ca. 1360-1387 B2020a:6.16); William Heytesbury (ca. 1313-1372; B2020a:6.17); Albert of Saxony (ca. 1316-1390; B2020a:6.18); Nicholas Oresme (ca. 1320-1382; B2020a:6.19); Marsilius of Inghen (ca. 1340-1396; Beukes 2020e); Peter of Candia (ca. 1340-1410 B2020a:6.22); Hasdai Crescas (ca. 1340-1396; B2020a:6.23); Blasius of Parma (1347-1416; B2020a:6.24); Catherine of Siena (1347-1380; Beukes 2020b); Peter of Ailly (ca. 1350-1420; B2020a:6.26); Jean Gerson (1363-1429; Beukes 2020d); Paul of Venice (1369-1429; B2020a:6.28); Hieronymus Pragensis (1370-1416; B2020a:6.29); John Capreol (1380-1444; B2020a:6.30); Paul of Pergula (d. 1455; B2020a:6.31), Gaetano of Thien (1387-1465; B2020a:6.32): Heymerik van de Velde (1395-1460; B2020a:6.33): Gabriel Biel (1408-1495; B2020a:6.34): Denis de Leeuwis ('the Carthusian', 1402-1471; B2020a:6.35), and Peter of Rivo (1420-1500; B2020a:6.36).

8.Of course, Robert Kilwardby belongs to this understated company as well. For an example of a reappraisal of an understated period in Medieval philosophy, see example of a reappraisal of an understated period in Medieval philosophy, see thinker, see Beukes (2011) concerning Peter Abelard (1079-1142). be illustrated with the image of an hourglass: the small and narrow niche is engaged from broad introduction research, working through the slim and specialised outputs, eventually moving back to the broader discipline, with a reworked version of the particular niche contribution. There would always be specialist researchers who are content to remain within and guard the unique narrowness and restrictedness of their particular niche (however, with the unfortunate consequences of isolation and alienation, overburdened and quarrelsome polemics about issues nobody else understands or the formation of morbid and self-imploding cliques). In the same vein, it could be suggested that there would always be researchers who eagerly take note of what is eventualising in niches, but who are not willing to engage a niche themselves or rework what has been carried in a niche for the sake of broader discipline. In both cases, the canon of Medieval philosophy remains unaffected as it has been for a very long time.

Consequentially, regarding the realm between niche research and introduction research, there should be a third domain of research in Medieval philosophy, which could thus be referred to as 'hourglass research', comprising scholars who themselves may be working in a specific niche (in the author's case, for example, focussing on unconventional receptions of Medieval thinkers and texts), but who are more interested in facilitating the hourglass dynamics by moving beyond their own niche and research objectives; or otherwise, willing to combine efforts from specialist colleagues to present accessible introductions to the broader discipline. From this middleposition, at once both 'outside' introduction research and 'inside' niche research (and vice versa), with the explicit intention to rework niche outputs for (or on behalf of) the broader discipline of Medieval philosophy and the subject of philosophy, the canon's gripping domination of the standardised contents of the discipline's index could be effectively challenged. The intention certainly is not to demolish the canon but to radically expand it beyond its current (and historical) self-presentation: ironically, the canon is being stabilised precisely when it is being destabilised and opened up. When the niche-isolated Medieval thinkers are illuminated from the dusky enclaves of hyper-specialisation, the subject of philosophy and the discipline of Medieval philosophy are themselves being illumed. The hourglass could then be turned upside-down, and the reworking process could repeat itself regarding the same thinker in a different niche, or an altogether different thinker, or a related thinker, or another topic in toto. In this way, research possibilities in Medieval philosophy have increased drastically: There would always be new and original work to do, as old as this discipline and her faithful departed exponents are (of course, this premise applies to any other subject, discipline or sub-discipline in contemporary science, which is being dissipated by the demands of hyper-specialisation). When the canon of Medieval philosophy is challenged in this way, there is lesser prioritisation of reception; in other words, the challenge is rather to be working with discursive, marginal units in the history of ideas than to merely repeat the contents of a canon, which spontaneously resists any objection to its stronghold on 
the discipline. The 21st-century research challenge in the discipline of Medieval philosophy is in this sense to bend the contours of the canon and, via reappraisals of niche outputs, to undermine the monopoly of the canon. This article is to be read as an address to this highly contemporary imperative in the discipline. ${ }^{9}$

Now, Kilwardby is a good example of a Medieval philosopher who is being analysed extensively in a particular niche (in fact, since 1937, with Sommer-Seckendorff"s groundbreaking work), but who remains an understated and rather unappreciated figure in Medieval philosophy, that is, outside the delineations of expert research. Few introductions, thematic expositions and readers, even from the past two decades, give from their overviews ample consideration to Kilwardby's scholastic and philosophical legacy. ${ }^{10}$

It is evident from the last footnote that references to Kilwardby in even very recent introductions are infrequent and scarce. Kilwardby is in this sense typical of a non-canonised thinker in Medieval philosophy: being present in the corpus' specialised exegesis, yet somehow absent in the introduction research and altogether mute in the broader subject of philosophy. The Kilwardby niche research, on the other hand, is lively and vibrant: specialists such as A. Broadie, $\mathrm{H}$. Lagerlund, A. Maierù, J.F. Silva and P. Thom have over the past years presented in-depth analyses of themes in Kilwardby's extant texts and have enriched the particular niche research. However, in precisely a contribution from what has been labelled 'hourglass research' supra, these

9.For similar challenges of the canon in the author's most recent work, see Beukes (2019b, 2019c, 2019d, 2019e, 2019f, 2020b, 2020c, 2020d, 2020e, 2020f, 2020h).

10.We encounter, for example, only arbitrary references to and brief discussions of Kilwardby in the following, recent, introductory and thematic works: the otherwise important and inclusive editorial reader of Bosley and Tweedale (2004) did not contain any reference to Kilwardby; the philosophical dictionary of Brown and Flores (2007:246) contained a short reference of two paragraphs; Canning (1996) made no reference to Kilwardby; Colish (1999:338) contained no reference to Kilwardby; Copleston's (1993:431-432) standardised introduction contained one reference consisting of a single paragraph; Dronke's (1988:181[fn. 20]) highly

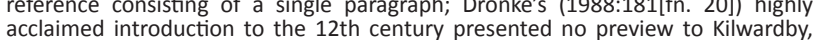
with the exception of one reference per footnote; the relatively recent and highly with the exception of one reference per foothote; the relatively recent and highly inclusive editorial work of Gracia and Noone (2006) presented the most importan biographical and bibliographical information effectively via the contribution of Broadie (2006:611-615); Grant's thematic introduction (2004:151) presented a short overview of three paragraphs with reference to Kilwardby's natura philosophy; Hannam's (2009) thematic introduction contained no reference to Kilwardby; Haren's (1985:150, 206-210, 235, 249) outstanding institutionalhistorical introduction offered an excursion on Kilwardby's role as ecclesiastical official; the commended thematic introduction of Hyman, Walsh and Williams (2010:410; 539), however, contained only two short references to Kilwardby's ecclesiastical contributions; Kenny's (2005) chronological introduction did not refer to Kilwardby at all; Koterski's (2009) conceptual introduction made no reference to to Kilwardby at all; Koterski's (2009) conceptual introduction made no reference to Kilwardby; the celebrated systematical introduction of Kretzmann, Kenny and Pinborg (1982:257; 281 [fn. 41]; 284-293; 483-484; 524; 636; 658; 677) presented a thorough overview of Kilwardby's theology and philosophy, as well as a shor biographical note (884); the new encyclopaedia by editor Lagerlund (2011:11481153) offered an excellent overview by the renowned Kilwardby-specialist Silva (2011); Luscombe's introduction (1997:116, 118, 167) contained three shor references to Kilwardby; Marenbon's $(2007: 221$, 225, 269) exceptional introduction in so many other respects contained only three cryptic references to Kilwardby whilst his previous introduction to later Medieval philosophy (Marenbon 1991) made no reference to Kilwardby at all; and again his editorial work (ed. Marenbon 1998) contained only three references via the contribution of Ebbesen (1998:271 280,288 ) in the context of the Paris arts faculty in the second half of the 13th century; Martin's (1996) introduction contained no reference to Kilwardby; McGrade's extensive editorial work (ed. 2003) contained only three references, on (in a footnote) by Marenbon and Luscombe (2003:70: [fn. 16]), one by Ashworth (2003:80; 94) and another by Pasnau (2003:217): the first volume of the editoria introduction of Pasnau and Van Dyke (ed.2010a) did contain a few references to introduction of Pasnau and Van Dyke (ed. 2010a) did contain a few references to Kilwardby in the contributions of Luscombe (2010:70; 72), Putallaz (2010:109; 110 [fn. 34]), Read (2010:177; 178 [fn. 28]) and Rosier-Catach (2010:203-206; 207 [fn. 45]; 209; 211-212); the second volume (ed. Pasnau \& Van Dyke 2010b) contained
two references to Kilwardby in the contribution of Conti (2010:648-650) as well as two references to Kilwardby in the contribution of Conti (2010:648-650) as specialist researchers combined their efforts to accessibly present Kilwardby's life and scholarship in a recent editorial work, A Companion to the Philosophy of Robert Kilwardby (Lagerlund \& Thom 2013). This work forms part of a broader contemporary initiative by the prestigious Dutch publishing house, Brill (Leiden, the Netherlands) to present accessible, philosopher-specific editorial works from specialist research, titled Brill's Companions to the Christian Tradition, under the chief editorship of C.M. Bellito. Besides Kilwardby, several other non-canonised thinkers from the Middle Ages have already been disseminated over the past few years in an attempt to further the legitimacy of (and the intense need for) 'hourglass research' in the discipline. ${ }^{11}$

This initiative of Brill ${ }^{12}$ under the guidance of the principal editor should have the full support of every lecturer, advanced student and introduction researcher in the discipline of Medieval philosophy: This series enables the discipline to introduce Medieval thinkers into the curriculum that are conventionally not included in introductions - and present these thinkers from indeed the most erudite scholarship. How enriching would it be for the discipline if both advanced undergraduates and postgraduate students would hereby be enabled to engage Medieval thinkers outside of the canon and be absorbed by the many thinkers on the margins of the canon instead of 10

11.Especially regarding John of (Jan van) Ruusbroec (Arblaster \& Faesen 2014), Giles of Rome (Briggs \& Eardley 2016), Walter Burley (Conti 2013b), Francis of Marchia (Friedman \& Schabel 2006), John of Salisbury (Grellard \& Robert 2015) (Friedman \& Schabel 2006), John of Salisbury (Grellard \& Robert 2015), Gerson (ed. McGuire 2006), Bernard of Clairvaux (ed. McGuire 2011) and Gerson (ed. McGuire 2006), Bernard of Clairvaux (ed. McGuire 2011) and Marguerite Porete (ed. Terry \& Stauffer 2017). The series involves some of the
canonised thinkers as well, with fresh premises for investigation and analyses, such as Resnick's (ed. 2013) outstanding editorial work on Albert the Great, and the solid presentation from all the contributors in Wilson's (ed. 2011) companion to Henry of Ghent. However, it seems that the editorial work that provided impetus for this 21st-century 'hourglass' initiative was Thijssen and Zupko's (ed. 2001) acclaimed work on John Buridan's metaphysics and natural philosophy: The other works listed above conform to a significant extent to Thijssen and Zupko's structuring and indexing, namely, to start with a biographical and thematical introduction by the editor(s), followed by contributions from the main Medieval sub-disciplines, notably cosmology (and natural philosophy), epistemology, metaphysics, psychology and ethics (which includes political theory).

12.Brill (not to diminish in any way the efforts and initiatives of any of the other outstanding publishers in the field, such as Brepols [Turnhout, Belgium], Walter de Gruyter [Berlin], Cambridge University Press and Oxford University Press) has, of course, over the years published many important monographs and other editoria works on both canonised and non-canonised thinkers from the Middle Ages. Compare, for example, these excellent in-house publications from only the past two decades: Aertsen and Endress (1999, on Ibn Rushd [Averroes]); Belo (2007, on Ibn Sina [Avicenna] and Ibn Rushd); Bertolacci (2006, on Ibn Sina's Aristotelian metaphysics); Bonner (2007, on Ramon Llull); Brown, Dewender and Kobusch (2009, on intellectual debates in 14th-century Paris); Bullough (2004, on Alcuin of York); Courtenay (2008, on Ockham); De Haas, Leunissen and Martijn (2011, on the interpretation of Aristotle's Posterior Analytics from late antiquity to the Middle Ages). Folger-Fonfara (2008) on the Francis of Marchia; Fortenbaugh (2006, on the Ages); Folger-Fonfara (2008) on the Francis of Marchia; Fortenbaugh (2006, on the reception of Aristotle's psychology, ethics and political theory in the Middle Ages); Gutas (2014, on Ibn Sina and the Aristotelian tradition in the Middle Ages); Hoenen and Bakker (2000, on Marsilius of Inghen); Kirchhoff (2008, on William of Sherwood); Klein-Braslavi (2011, on Gersonides [Levi ben Gershom]); McGinnis and Reisman (ed. 2004, on science and philosophy in Medieval Islam); Palmén
(2014, on Richard of St Victor); Pascoe (2005, on Peter of Ailly); Pelletier (2013, on (2014, on Richard of St Victor); Pascoe (2005, on Peter of Ailly); Pelletier (2013, on
Ockham); Pickavé (2007, on Henry of Ghent); Reisman (2002, on the Avicennan tradition in Medieval philosophy); the brilliant editorial works of Evans (2002) and Rosemann (ed. 2010, 2015) on Medieval commentaries on the Sententiae of Peter Lombard, with focus precisely on the non-canonised thinkers' receptions Rosenthal (2007, on epistemology in Medieval Islam); Schabel's exhilarating twovolume (ed. 2006, 2007) editorial introduction to quodlibeta in the 13th and 14th centuries; Schweid (2008, on Medieval Jewish philosophy); Silva (2012, on Kilwardby's psychology); Šmahel's editorial (ed. 2007) on the crucial role played by the University of Prague in the later Middle Ages; Suto (2012, with a remarkable re Univar (2007, on Marsilius of Padua's political theory); Thom (2007, on Kilwardby's logic and ontology); Toivanen (2013, on Peter Olivi's epistemology and psychology); Treschow, Otten and Hannam's (ed. 2007
extensive introduction to ancient and Medieval doctrines of creation); Wagner (2008, on the conception of time from Aristotle through the Middle Ages); Warnar (2008, on the conception of time from Aristotle through the Middle Ages); Warnar
(2007, in a gripping work on Jan van Ruusbroec) and Wood (2012, on Isidore of (2007, in a gripping work on 
or perhaps 15 canonised thinkers that are apparently considered to be mandatory for the curriculum? 'Hourglass research' could open up a discipline that is often experienced by contemporary students as static and rigid - and present to novices in the field some of the most exciting developments in the thought of some of the unknown philosophers from Middle Ages. Besides, 'hourglass research' enables scholars in the field to publish on themes outside of their immediate expertise and to contribute to the broader well-being of the discipline of Medieval philosophy: this is also the sub-text and second intention of this article.

\section{A promising schoolman at the universities of Paris and Oxford,}

\section{ca. 1231-1256}

Robert Kilwardby ${ }^{13}$ (Latinised: Robertus Kilewardbii; de Kilvarbius) was already, in his times, noted and recognised as an exemplary intellectual and prominent figure in the young 13th-century Dominican order of England. According to his only modern biographer, Sommer-Seckendorff (1937:ix; cf. Lagerlund \& Thom 2013:1), he was a distinguished schoolman and eminent ecclesiastical official, always in touch with the tempestuous intellectual and political climates of his troublesome days. Born in England and educated in philosophy, both as a baccalaureus and magister in Paris, Kilwardby presented a unique contribution in the overlap from early scholasticism to high scholasticism from his original base, the University of Oxford, in the second half of the 13th century - however, not without conflict and a serious complication. He was appointed archbishop of Canterbury in 1272 and became cardinal in 1278 , a year before his passing.

Apart from being outside the canon, Kilwardy is for another reason an understated figure in Medieval philosophy because of the authority of his two renowned Dominican counterparts, Thomas Aquinas (1225-1274) and Albertus Magnus ('Albert the Great', ca. 1200-1280). It was because of the prominence of these two Dominican stalwarts that some of Kilwardby's works would only be edited in the second half of the 20th century, with a significant number of his works yet to be edited in Latin and translated from Latin even in the second decade of the 21st century. The Kilwardby niche research is nevertheless focussed on rehabilitating Kilwardby from apparent oblivion as an early scholastic who influenced later scholasticism significantly with his interpretation of Aristotelian logic and his reinterpretation of the place of grammar in the old trivium (alongside logic

13.From the recent 'hourglass' research, it thus becomes possible to profile Kilwardby responsibly and concisely for the sake of the broader discipline: compare, against
the background of the previous three footnotes, Kilwardby's primary texts (1976, the background of the previous three footnotes, Kilwardby's primary texts (1976, 1982-1995, 1987, 1993) as well as Broadie (2006:611-615); Celano (1999:149-162, 2013:315-352); Conti (2013a:65-13); Corbini (2013:163-208); Tonat (2013:230-274); Gal (1953.7-28), Kneepkens (2013:17-64), Lagerlund and Thom (2013:1-16); Lewfy (1981, 1983:1-42); Maierú (2013.353-390); McAleer (1999:33-54); Sommer-Seckendorff (1937:i-x; although dated, never expendable), Thom (2007:1-10, 2013:131-162); Trifogli (2013:209-238) and Silva (2011:11481153, 2012:1-26, 2013:275-314) and rhetoric), as well as his idiosyncratic synthesis of Augustinian and Aristotelian elements in the standardised reception of both traditions in the 13 th century.

Similar to most early scholastic philosophers, ${ }^{14}$ Kilwardby's life and academic work were determined decisively by two institutional developments, namely, the establishing of the first universities (by the 1200s already more than a century old, after the founding of the studium generale in Bologna in 1088, followed shortly thereafter in Paris [1150] and Oxford [1167, although teaching commenced in 1096]), as well as the founding of new mendicant orders (i.e. orders independent of the established monasteries), with specific reference to the Franciscan and Dominican orders' adjoining development from around 1210. During the best part of the 13th century, Kilwardby was a central figure in both these institutional branches, as a schoolman at the university, a mendicant monk in the Dominican order and an official in the ecclesiastical hierarchy of the church in England, two centuries before it was separated from Rome in 1534 (to become the Church of England). In these capacities, four dates can be biographically pinpointed: Kilwardby's election as prior of the English Dominicans in 1261, his appointment as archbishop of Canterbury in 1272, his (controversial) promotion as chancellor in 1278 and his death in 1279 , all documented with precision. Because it is equally well documented from university records that he progressed through all the postgraduate requirements to become master of arts by the end of the 1230s, a biographical overview should only rely on information gathered from his education in Paris, his return to England to be trained in theology and the ways of Dominican life, and the last part of his life as a senior ecclesiastical official.

As is the case for many mendicant monks and schoolmen, Kilwardby's date and place of birth are unknown; however, if his surname correlated with the district from which he adhered, as was the case for most Medieval monks, Kilwardby was originally from either Leicestershire or Yorkshire (inferred by Sommer-Seckendorff 1937:3). By referring the dates of his baccalaureus in arts (1231) and magister in arts (1237) at the University of Paris back to a possible date of birth, it appears to the author that 1215 is the most plausible year of his birth: Kilwardby would not have been able to start undergraduate classes in Paris before the age of 16 (thus 1231) and would not have been able to complete the postgraduate course in less than 5 years (thus 1237, at the earliest). From 1238 to 1245,

14.'Early scholasticism' in the author's periodisation Beukes (2011:1544; 2018 : 1 ; $2020 \mathrm{a}: 5$ ) refers to the period 1088 (the founding of the University of Bologna) to 1225 (the birth of Aquinas) and comprises the following philosophers: Bernard of Clairvaux (1090-1153), Peter Venerabilis (ca. 1092-1156), Peter Lombard (10951160), Hugo of St Victor (1097-1141), Hildegard von Bingen (1098-1179), Peter Helias (ca. 1100-1166), Richard of St Victor (d. 1173), John of Salisbury (ca. 11151180), Gundissalinus (ca. 1110-1190), Ibn Rushd (Averroes, ca. AH 520-595/ca. 1126-1198), Alan of Lille (d. 1203), Moses Maimonides (1138-1204), William of Auxerre (ca. 1140-1231), Phillip the Chancellor (1165-1236), Robert Grosseteste (ca. 1168-1253), Alexander of Hales (ca. 1185-1245), William of Auvergne (ca. (ca. 1168-1253), Alexander of Hales (ca. 1185-1245), William of Auvergne (ca. 1180-1249), John of Rochelle (ca. 1190-1245), Albertus Magnus (ca. 1200-1280), William of Sherwood (ca. 1200-1271), Richard Fishacre (ca. 1205-1248), Mechtild von Magdeburg (ca. 1207-1282), Richard Rufus van Cornwall (fl. 1231-1256), William Arnaud (fl. 126 Roger Bacon (1214/20-1292), Kilwardby himself, Bonaventura (1217-1274), Hadewijch of Antwerp (fl. 1240), Henry of Ghent (d. 1293) and Ulrich von Strassburg (ca. 1220-1277). 
Kilwardby's academic endeavours at Paris were documented meticulously on the grounds that he distinguished himself in lectures on the trivium as well as that the number of original readings and commentaries that he presented in Paris during this stint far exceeded the outputs of even those of the established magistri. Similar to many of the most exceptional schoolmen from the 11th century to the 14th century, Kilwardby was a double master, in that he eventually acquired the highest qualification in both arts (philosophy) and theology. A Medieval magister in arts (roughly equivalent to a contemporary doctorate in humanities, however, then with greatly more rigorous requirements for obtaining the degree) could not be promoted to magister in theology in Paris before the age of 35, even if all academic requirements had been met at the time (Aquinas was an exception, having been awarded the degree in 1256 at the age of around 30, by controversial papal decision). It is unsure whether Kilwardby already turned 35 by 1245 (if 1215 is accepted as a possible date of birth, it obviously is not so); whatever be the case, Kilwardby opted not to remain at the theology faculty in Paris, undoubtedly already a master of arts at the time, but to return to England. The University of Oxford had already established itself as a centre of excellence for graduate and postgraduate studies in theology: Robert Grosseteste (ca. 1168-1253) was a magister and chancellor of the university from 1221, Roger Bacon (1214/20-1292) famously obtained his baccalaureus there under Grossesteste's supervision, whilst renowned 13thcentury magistri in theology such as William of Sherwood (ca. 1200-1271), Richard Fishacre (ca. 1205-1248) and Richard Rufus of Cornwall (fl. 1231-1256), all hailed from Oxford. Upon arrival at Oxford in 1245 , Kilwardby immediately joined the local Dominican studium, which structurally by 1250 flourished in England, with more than 600 members lecturing and preaching in most cities and large towns, without placing any financial burden on those communities. ${ }^{15}$

The academic climate at Oxford, combined with the public intellectual profile of the Dominicans, enabled the young arts master Kilwardby to make swift progress in theology in his homeland - after completing the extremely challenging curriculum for the Oxford magister in theology from 1246 to 1251, he finished the mandatory commentaries and lectures on Peter Lombard's Sententiae by 1254 and the compulsory lectures on Biblical exegesis by 1256. At the end of 1256, Kilwardby was promoted to magister in theology of Oxford, becoming a double master of both philosophy and theology, at the two most eminent universities of that time. He was appointed supervising master or magister regens of the Dominicans at Oxford directly after his promotion, which bears witness to his authoritative academic reputation.

15. However trivial, it is important to stress that the Dominicans excelled in providing high-quality free education and public homilies in the communities they were involved in (therefore, named Ordo Praedicatorum [Order of the Preachers, O.P.] vis-à-vis the Franciscans, who accentuated modesty in its charity, diaconal enterprises and care for the community [aptly named Ordo Fratrum Minorum, Order of the Humble Brothers, O.F.M.]). This does not imply that the Franciscans were of the Humble Brothers, O.F.M.]). This does not imply that the Franciscans were somehow less ferocious in dealing with intellectual and scholastic matters than the Dominicans, but merely that the way in which these two orders deployed themselves socially, differed significantly. In many respects, as became evident in the first half of the 14th century, under the guidance of the highly skilled Franciscan schoolmen such as John Duns Scotus (ca. 1266-1308) and William of Ockham (ca. 1285-1349), the Franciscans indeed surpassed the Dominicans in intellectual debates, especially in the intense scholastic confrontations from the 1280 s to the 1350 s.
Kilwardby worked in and from Oxford for the next 16 years, progressively accumulating responsibilities directed from the Dominican leadership. In 1261, he was appointed prior of the English Dominicans (and reappointed in 1272), a position which brought him into close contact with prominent Dominicans of other countries (or 'provinces', in mendicant lingua), notably Aquinas (then advisor at the papal court) and the French magister Pierre de Tarentaise (1225-1276, who later became pope [Innocent V] from 01 January to 22 June 1276). He attended the general council of the Dominicans in 1263 in London in the company of Aquinas and Tarentaise, whilst he was hosted for the duration of the general council in 1271 in Montpellier by Albertus Magnus.

In the same year, the master general of the order requested Kilwardby to present a theological answer to 43 debated questions, to which he immediately agreed. His answers were deemed to be so erudite that they were sent to Aquinas and Albertus for commentary, and both accepted Kilwardby's answers without amendment and actually utilised his answers in their commentaries on the very same 43 questions. This subtle exchange pointed towards Kilwardby's growing stature, his progressive influence in the order and his esteemed presence in the scholastic environment of the second half of the 13th century. As a result of this, Kilwardby was appointed to the eminent position of archbishop of Canterbury in 1272, where he served with distinction until 1277 (see Figure 1), when things changed somehow. In this capacity, he nevertheless moved freely and was respected in

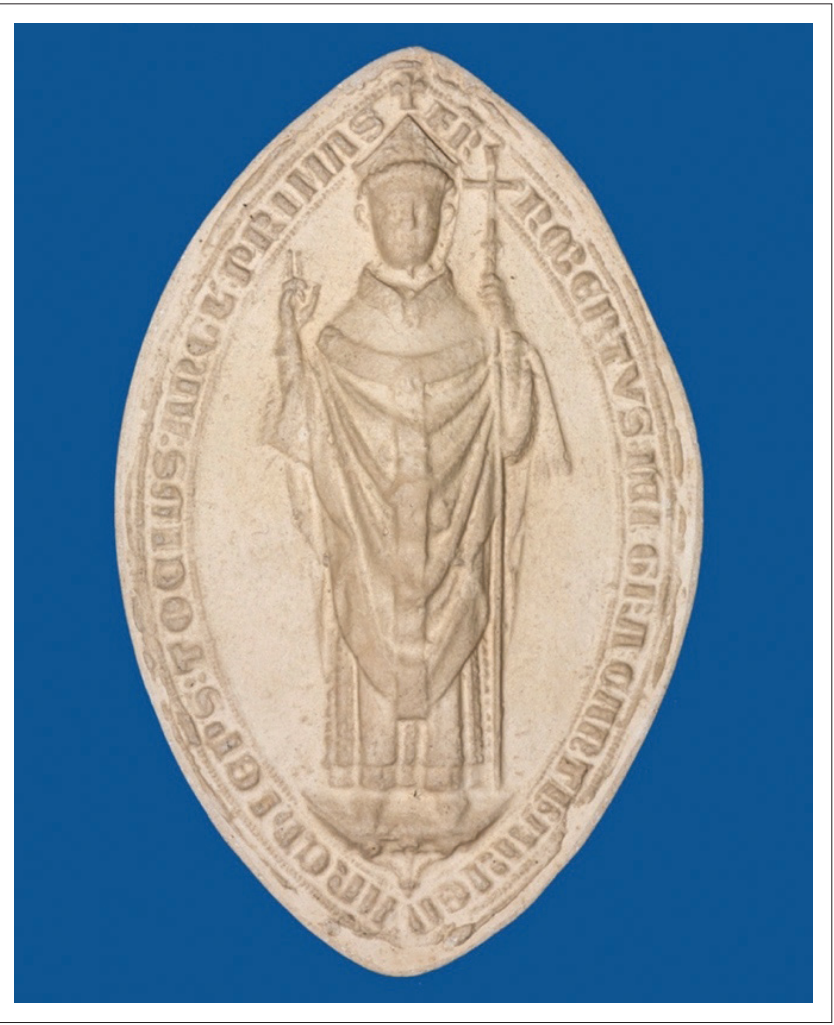

Source: Lagerlund, H. \& Thom, P., 2013, 'Introduction: The life and philosophical works of Robert Kilwardby', in H. Lagerlund \& P. Thom (eds.), A companion to the philosophy of Robert Kilwardby, pp. 1-16, Brill, Leiden.

FIGURE 1: The seal of archbishop Robert Kilwardby of Canterbury, 1272-1278. 
the highest educational, religious and political circles in England and on the European continent: He participated inter alia in the Second Council of Lyon in May 1274 and crowned Edward I at Westminster Abbey on 19 August in the same year. The correspondence between Edward and Kilwardby indicates that the king and the bishop maintained a sincere and steady relationship, leading to Edward's permission at the Dominicans' request to move their historical centre from Holthorn, where it hosted the order's activities since its inception in 1223 , to a locality between the River Thames and Ludgate Hill, where it acted as the order's headquarters in England until 1538. The king was a frequent and welcomed guest at Ludgate, still for centuries afterwards.

\section{An established natural philosopher in Paris and Oxford, 1238-1259}

Before turning our attention to Kilwardby's role as an ecclesiastical official, his scholastic output should be accurately noted, as it provides the theoretical framework for the institutional decisions he eventually and controversially made in his capacity as archbishop of Canterbury from 1272 to 1278 - especially in the sense that he did not shy away from controversy and polemical standpoints. The index of Kilwardby's philosophical and theological texts was compiled by the Dominican librarian Nicolas Trivert (ca. 1257-1334), with additional credit to the editorial efforts of a subsequent monk, Laurence Pignon (ca. 1368-1449), who tabled the texts that could authentically be attributed to Kilwardby based on its source texts. ${ }^{16}$ These comprised commentaries on grammar and logic that Kilwardby wrote as magister of arts in Paris and magister of theology at Oxford: Porphyry's' Isagoge; Aristotle's Categoriae and De Interpretatione; Boethius' De divisione en Topica; again from Aristotle his two Analytics, Topica and Sophisticis Elenchis; as well as questions from Priscianum minorem and Sophisticam grammaticalem et logicalem.

In these commentaries, thus all written (predominantly) in Paris and (to some extent) at Oxford, Kilwardby's basic premise that grammar is a science, and therefore a university discipline, becomes abundantly clear: he comments on several passages from Aristotle's physics and natural philosophy, wherein he describes syntax as a scientific discipline and demonstrates the proclaimed scientific status thereof. Concepts such as action, potentiality and actuality should thus be considered syntactically and linguistically before they are analysed philosophically (Kneepkens 2013:19). In addition, a distinction must be made between Kilwardby's linguistic intentionalism and the sort of modalism, which in the later Middle Ages would attain a dominant position: where the later modalists accentuated the way in which the rules of grammar inhibit and restrict the use of a particular language, intentionalists, such as Kilwardby, simultaneously stressed these restrictions as well as the freedom of users of language to undermine those rules of grammar, for example, by employing analogical and research (Lagerlund \& Thom 2013:8), which is quite remarkable. metaphorical language. In these commentaries, Kilwardby accordingly presents his theory of double intellectus, by which he indicates a combination of factors that are prerequisites for a figurative and deviant use of language: the sapiens or wise person is precisely the person who can deviate responsibly from within established rules of grammar to transfer or communicate an intended meaning or intentional reference. In this regard, Kilwardby flanks the very similar and established theory of Augustine, realising how consequential the theory of double intellectus theologically is.

In the Paris commentaries, Kilwardby's interpretation of the relation between being and logic is also presented: he surveys in his commentary the 'old logic' or logica vetus, the Aristotelian concept of being, concerning the concepts substance, accident, universality, individuality, individuation and matter. It is precisely in these deliberations that Kilwardby's dependence on Augustine is sharply delineated (Conti 2013a:65-13). The young Paris master analyses logical principles from Aristotle's physics and metaphysics and then examines the contradictions that arise when these principles are applied to patristic literature. For example, Kilwardby argues that universals could be considered in terms of both the existence thereof in individuals and the mind. However, he immediately also accepts the Augustinian notion that the universal already and always exists in the mind of God, even if all individuals in which that universality once was established, ceased to exist. We encounter other Augustinian influences in the Paris commentaries as well, amongst others, in Kilwardby's acceptance of a plurality of substantial forms in composed substances, the notion of active potentiality in matter, the presence of seminal causes in matter and individuation through both form and matter. In his discussion of the Isagoge, Kilwardby argues for materiality in the angel intelligences, by which he (at the time, controversially so) accepted universal hylomorphism (see infra; a position which he would later defend in Oxford in his Epistulae).

The same mixture of Aristotelian natural philosophy and antiquated Medieval material is encountered in Kilwardby's assessment of Aristotle's Analytica Priora (Thom 2013:275-314). Kilwardby approaches Aristotle's text sympathetically but adds several original passages of commentary, which expand and deepen the original text, especially regarding modal syllogisms. These passages initially still draw conceptually on Aristotle's natural philosophy and metaphysics, still employing the four Aristotelian causes in his definition and interpretation of syllogisms: he argues that the syllogism's final cause is the demonstration of the truth value of a categorical proposition. However, Kilwardby understands the material and formal causes in characteristically Augustinian fashion, namely, that a syllogism consists of a plurality of forms and can itself be incompletely formed. In other words, nothing is 'pure form' and even an abstract syllogistic formula consists of a material component of some kind, for example, $A$, $B$ or $C$, which constitutes a 'transcendental matter'. Of course, syllogistic forms primarily belong to two or a 'couple' of premises, but Kilwardby argues that not all such 'couples', which make deduction possible, possess a syllogistic form. In 
fact, he demonstrates that some deductive inferences, which could be reduced to a perfect Aristotelian syllogism, have no syllogystic form. Also, Kilwardby's commentary on Aristotle's Analytica Posteriora intentionally synthesises Aristotelian natural philosophy with traditional Augustinian ideas (Corbini 2013:163-208). This synthetic ideal was already present in his Oxonian forerunner Robert Grosseteste's commentary on the same text, and Kilwardby employs several aspects of Grosseteste's analysis. However, again Kilwardby moves beyond the contemporary reception in his use of the concept of universality: For him, 'universal', on the one hand, refers to something in the divine intellect, and, on the other hand, to something immanently present in things, determining the nature and character of those things. The first is unmistakeably Neoplatonic, of which again only Augustine could have been the source.

Kilwardby's original works (indexed and edited initially by Trivert and Pignon as well) comprises De tempore (finally edited only in 1987, as 'On time'), De universale ('On the universe'), De relatione ('On the relation' [God and humankind]), De spiritu fantastico (re-edited in 1987, as 'On the imagination'), De ortu scientiarum (re-edited in 1976, 'On the sciences') and Quaestiones in libros Sententiarum (re-edited from 1982 to 1995, 'Questions on [Lombard's] Sententiae'). In De tempore, Kilwardby argues (Trifogli 2013:209-38) that time possesses a unity, which is a successive and ongoing quantity, established intrinsically in movement: every moving thing possesses this quantity according to its nature. Time, like movement, is a successive phenomenon: the parts of time, such as the parts of movement, do not exist concurrently, but in succession. Kilwardby claims (remarkably 'protoquantum') that a parallel exists between space and time, on the basis of which time must be depicted as mind-independent.

In De ortu scientiarum, Kilwardby investigates the nature of matter against the background of Ibn Gabirol's (Avicebron, Beukes 2020a:3.5) theory of universal hylomorphism, which means that the universal element (or principle of classification) is immanent in the thing. Something like a matter - or form analysis exists for all created beings, including spiritual substances. Kilwardby affirms the (for him) validity of the theory, but because of his extreme alertness to homonyms (where two or more words with exactly the same form have totally different meanings, for example, 'bank': 'I go to the bank to deposit money', 'We fish from the bank of the river'), he distinguishes a general meaning of the word 'matter', wherein spiritual substances possess matter, from the strict Aristotelian sense of the word 'matter', according to which spiritual substances do not possess matter (Donati 2013:23974). Kilwardby argues that the general meaning of the particular word is the genus generalissimum of substance. In the more restricted and non-general sense, the word could include further specifics such as 'bodiliness', 'extension' or 'to-be-extended-from': this is a formed matter. He defends the theory of the active potentiality of matter in the latter, restricted sense, by claiming that the theory presents an explanation for the fact that matter could accrue a new form, without having to accept that the form was already present in the thing, on the one hand, or that the form was externally forced onto the thing. Matter, in the general or genus generalissimum sense of the word, could be considered in terms of the essence thereof (thus, in itself) or in terms of the existence thereof (thus, in conjunction with its form). Furthermore, Kilwardby allows for different kinds of primary matter, which could be distinguished based on the more of lesser 'purity' thereof.

Kilwardby also presents his psychology in De ortu scientiarum: it is precisely in his theory of the soul where Kilwardby's teaching on the plurality of substantial forms is being clarified (Silva 2013:275-314). He argues that the human subject is composed of two substances. Both substances involve matter and substantial forms, from which the vegetative and sensitive potentiae are generated naturally. The intellective potentia was, however, created by God and is being expressed by God in the individual person. These three potentiae exist concurrently but only postquam est homo (i.e. when the human foetus is formed and thus acquired the form of a human being, ultima forma). In De spiritu fantastico, Kilwardby (1987) surveys empirical observation, which he considers to be a subcategory of psychology. Again flanking Augustine, he maintains that empirical observation is active and that the soul is the effective cause of sensorial experiences: $\mathrm{He}$ combines this perspective with an Aristotelian version of the proceedings of active intellect in the presentation of a theory of abstraction.

A last noteworthy aspect of Kilwardby's original philosophy is his relatively drastic perspectives on ethics. The apparent radical nature thereof must, however, be interpreted within the Aristotelian context of other 13th-century ethical commentaries: whilst Aristotle's theories of the good, the virtue and the human happiness were still underdeveloped in the 1230s, the high scholastics in the second half of the 13th century started to systematise Aristotle's ethical perspectives more coherently. Of these, Albertus Magnus' extensive ethical commentary was the first and the most pivotal one, followed by Sherwood, Fishacre and Rufus who extended Albertus' Aristotle reception. Kilwardby pulled this trajectory from Albertus to his contemporaries through its fullest consequences: he starts by dividing ethics into two sections, namely, happiness, as the highest human good, and the virtues, which has its primary objective to express the highest good. Kilwardby circumvents the so-called 'theological virtues': he argues that Aristotle himself never considered these kinds of virtues in his Ethika and that responsible ethics should focus only on what could be considered in the mundane life. The religious virtue of beauty, for instance, could, according to Kilwardby, not be indexed under philosophical ethics; it belongs to theology as such. Kilwardby's consistent shadowing of Aristotle in terms of ethics presented a watershed in the move from early scholasticism to high scholasticism, where the theological virtues featured as a focal point in the works of early scholastics, such as Bernard, Venerabilis, Lombard, Hugo and Helias; the importance of these virtues were progressively minimalised from Albertus onwards and effectively dismissed by Kilwardby. 
After Kilwardby, the consideration of theological virtues would seldom occur in philosophical discourse: ethics from Kilwardby onwards becomes a profound secular concern, with the presupposition that the good for and from God belongs to an altogether discourse, namely, theology. The typical early scholastic distinction between theology and philosophy was hereby realised in its logical and completest consequences. In this sense, Kilwardby was, in the company of other early scholastics such as Bonaventura, Henry of Ghent and Ulrich von Strassburg, a prominent transitional figure between early and high scholasticism.

\section{Archbishop of Canterbury, central in the Paris-Oxford condemnations of 1277}

During the period between 1272 and 1278, archbishop Kilwardby maintained his connection with the University of Oxford and played a crucial managerial role at the university's (later legendary) Merton College: he, for instance, declared a bishop's statute on Good Friday 1276 that the college acquired ownership of the books of all its fellows and that the original, as well as the first copy of the relevant manuscript, must be catalogued and safeguarded in the college library. This tradition is upheld till today at Merton College.

Kilwardby's term as archbishop, however, entered a shadowy phase in the first months of 1277 , and the resulting events would haunt him for the last 2 years of his life: appearances of institutional achievements aside, these events led, in fact, to his undoing. On 18 March 1277, Kilwardby called for an extraordinary convocation of Oxford masters to discuss his decision to condemn 33 texts in grammar, logic and natural philosophy, and put these writings on the index of prohibited literature. This assembly took place only 10 days after Ettiene Stephanus Tempier, bishop of Paris, condemned several texts from a variety of authors concerning 219 propositions, in what infamously became known as the Paris condemnations of 1277 .

With the continuous delivery of Aristotle's extant oeuvre in Latin from the first half of the 13th century onwards, based, of course, on the Arabic translations of the original Greek texts, there was discomfort amongst many Christian theologians about this development. The early scholastic William of Auvergne (ca. 1180-1249; cf. Beukes 2020a:4.17), for example, was convinced of the autonomy of philosophy in all matters philosophical and referred matters with a dominant philosophical character, back to philosophers for dissemination and commentary. The problem establishing itself was that this characteristic early scholastic division of philosophy and theology was rather inflexible and presented with much fervour, yet did not take into account the philosophical elasticity of theology nor the theological pliability of philosophy (at the time). As pertinently as these two disciplines or 'sciences' were at all costs kept apart from the beginning of the 12th century, the fact is that there were matters that always were closest at home in the Venn-diagram between philosophy and theology; in other words, matters that were as much 'philosophical' as they were 'theological'. This Venn-diagram is precisely what Auvergne encountered: as much as he wanted to channel 'philosophical matters' to 'the philosophers', he was not able to not engage several theoretical positions, particularly Aristotle and Ibn Sina. This was Auvergne's predicament: Greek and Neoplatonic philosophy had in the 12th century arrived in the Latin West to stay. An intellectual storm was slowly brewing as Auvergne had to concede the validity of this Venn-diagram, its impetus provided by the reception and application of Aristotelian philosophy by both arts and theology faculties at the University of Paris. Efforts to soften this 'pagan appeal' were unsuccessful, including the notorious ban on private and public lectures on Aristotle in Paris in the 1230s: with all its explosive consequences and negative exposure, many eminent philosophers and theologians simply continued to lecture on Aristotle in and outside of Paris, whilst several took refuge at the University of Oxford, where Aristotlestudies were in fact commended. The earlier condemnations of 1210 (where, amongst others, John Scotus Eriugena's [815877; cf. Beukes 2020a:2.2] Periphyseon was finally put on prohibited index), followed by similar denunciations in 1215 and 1231, proved to have no impact on the reality that theology always drifts to philosophy and vice versa. That is why, in spite of the prohibitions, Aristotle was again openly, if not confrontationally, lectured from the 1240s onwards.

However, precisely during the 1240s, another significant introduction took place, namely, the radical Aristotelianism of Ibn Rushd (Averroes, ca. AH 520-595/ca. 1126-1198). The temperate Aristotle reception of Ibn Sina now had to make way for outright polemical readings of Aristotle: Averroist theses would indeed be at the heart of literally every theological controversy from 1240 to 1277 . From 1240 onwards, it also became clear that the 'professional philosopher' - that is, one who specialises at the arts faculty without considering for a moment the possible theological repercussions of his work - is now a constant presence. The Averroists Siger (of Brabant, ca. 1240-1282) and Boethius of Dacia (fl. 1270-1280), two feisty and rather infamous magistri from arts in Paris, were clear examples of this audacious self-presentation of the 'philosophers' in the second half of the 13th century.

The dominant 13th-century Franciscan, Bonaventure (12171274), had warned repeatedly against what he considered to be the hubris of these 'philosophers', precisely in the sense that they were apparently not willing to discount for the logical consequences of their work in a context where theology still had the last word on all matters important; however, with no avail, as it became evident in the 1260 s that the Averroist thrust had become unstoppable. The Dominicans took note, however: Aquinas was called back to Paris in 1268 to act (for, at the time, an unprecedented second term) as magister regens or supervising lecturer, to eradicate what was now experienced as the emergence of a catastrophy at the University of Paris. By all his competence and erudition, Aquinas was not able to stamp out the fiasco: indeed, he himself eventually fell victim 
to it. On a breezy spring day, this storm that had been brewing for half a century, broke loose in Paris.

On 08 March 1277, Tempier condemned a list of 219 propositions, which he associated directly with the arts faculty in Paris: It was by far the largest and most consequential of all similar condemnations since the 11th century. Kilwardby, thus a former Dominican at theology in Paris himself, but now in his capacity as the highest ranking ecclesiastical official in England, condemned, in the immediate afterglow of the Paris condemnations, 30 propositions on 18 March 1277, all of which could be thematically linked to Tempier's 219 denunciations. Already in 1270 did Tempier condemn 13 propositions preliminarily, which were related to Siger's theoretical positions in particular: these included the existence of only one potential intellect; the eternity of the world and therefore of humanity; God's non-knowledge of individual particulars and therefore a lack of knowledge of all things external to God; and the renunciation of both free human will and God's foreknowledge. In the same year, as part of his redeployment by the Dominicans in Paris, Aquinas confronted Siger's Averroist interpretation of the potential intellect in his De unitate intellectus. Tempier's initial attack on the 13 propositions of Siger's work, however, only paved the way for what was to follow in $1277 .{ }^{17}$

17.For a thorough discussion of the events leading to the condemnations of 1277 the condemnations themselves as well as the 219 relevant propositions, see Beukes
(2020a:5.1). Briefly: in January 1277, Pope John XXI (Peter Juliani, ca. 1215-1277, (2020a:5.1). Briefly: in January 1277, Pope John XXI (Peter Juliani, ca. 1215-1277,
pope from 08 September 1276 to 20 May 1277) corresponded with Tempier about the pope's reserves regarding the radicalised Aristotelian ideas being circulated in Paris, with the arts faculty as its institutional source, now swiftly spreading to the Paris, with the arts faculty as its institutional source, now swiftly spreading to the
faculty of theology. Tempier, without direct sanction by the pope, summarily faculty of theology. Tempier, without direct sanction by the pope, summarily
assembled a study commission comprising 16 theologians (one of which was Henry of Ghent [d. 1293]), ordering them to investigate the suspect texts and present a list of censurable propositions. This study commission without delay presented the requested list, consisting of 219 propositions. However, the list itself was so incoherent and unorderly that it had to be re-edited several times, even into the 16th century. Nevertheless, it sufficed for what Tempier had in mind: penal sanctions against, including the excommunication of, any lecturer, author or student, who subscribed to any one or more of the 219 propositions privately or publicly. Students were indeed considered to be guilty of transgression if they had without immediate objection attended lectures on the issues at hand or made without immedlate objection attended lectures on the issues at hand or made iss effectively 1270; howeve Tempier personally listed th well as any theoretical position that potentially compromised either God's omnipotence or free human will in any way, including critical questions regarding the necessity of God. Nevertheless, in the end, Aristotle was the primary target, and the Neoplatonic interpretations of Aristotle, as encountered in Ibn Sina's emanation theories, were of secondary concern. Characteristic Aristotelian themes, including the eternity of the world and that God as Intellect only contemplates Godself, as well as a whole spectrum of pseudo-Dionysian and Arabic applications of Aristotle (especially regarding the unity of the potential intellect and indeed emanationism) were reworked and disseminated in a diversity of propositions, which eventually constituted the sum of 219. These disseminations and reinterpretations (of interpretations) of Aristotle were articulated and presented in such a way that they interpretations) of Aristotle were articulated and presented in such a way that they were plainly and - appar wormative Christian dogma of the late-13th century. particular, were listed: this included (Neoplatonic) speculations on the intelligences ('celestial beings' or 'angels') from a higher emanating Intelligence than humankin and critical questions regarding the revelation or knowability of God. The repudiation of the basic tenets of Aristotelianism and Neoplatonism was nonetheless not the only astonishing feature of the 219 condemned Paris propositions: precisely those propositions that dealt with the relation between morality and religion were presented in a highly polemical if not offensive fashion, quite foreign to the speculative nature of 13th-century Christian theology in general: firstly, any interpretation of philosophy (correctly defined as the 'search for rational knowledge that could be grounded scientifically'), which does not subordinate itself to the authority of theology and 'wisdom from revelation', was condemned outright: for example, propositions 177 and 200 affirm only virtues that are so-called acquired as indeed virtuous (i.e. through habit, discipline and practice; (rention ironically, a confirmation of Aristotle's position), whilst the so-called 'spontaneous Christian a confirmation (c) the human subject's answer to "grace alone becomes effectively obsolete). Propositions 171 and 211, in the same vein, postulated rather oddly that modesty in itself is not a virtue. Propositions 17, 18 and 25 questioned the necessity of the
The consequences of the condemnations of 1277 could be interpreted from two angles: in the first instance, there is no doubt that these condemnations irrevocably changed the history and face of philosophy. Philosophy would henceforth never be the same again, in the sense that the condemnations could either be regarded as a brutal triumph of Augustinianism over Aristotelianism, or ironically as the liberation of Aristotle from the radical readings of the Averroist Aristotelians, which in turn opened doors for the systematic Aristotelian development of natural sciences, without further dogmatic radicalisation, on the one hand, and theological intervention, on the other. Secondly, the condemnations of 1277, again ironically, changed the nature of scholastic discourse itself: the early scholastic differentiation between theology and philosophy, which was evidently an overwrought and non-sustainable distinction, was approached after the condemnations with less reserve (because the parameters of what may, and what may not, have now been established clearly). Scholastic thinkers in the later Middle Ages of the 14th and 15th centuries were at far greater liberty than their 13th-century counterparts to work both philosophically and theologically within the now-established boundaries as long as they kept themselves within the Parisian contours. The fact that Aquinas' condemnation was already withdrawn (followed soon by his formal canonisation) in 1323 worked towards this suppleness within the Parisian margins. Both these sets of condemnations in 1277, first in Paris followed only days later in Oxford, could be understood as the inevitable consequence of two centuries of intense institutional friction and mistrust between the church and the rising universities, with Aristotle being the central figure in this hazardous terrain.

Although Tempier and Kilwardy undoubtedly had contacts before March 1277, the events in Paris and Oxford in that month should not necessarily be understood as strictly overlapping. On at least three levels, the two sets of condemnations differ from each other: firstly, as clearly was not the case in Paris, none of the implied authors of the censured 33 texts at Oxford was stigmatised; secondly, none of these texts was declared as outright heresy; and thirdly, Kilwardby undoubtedly did not act under any orders of or requests from the pope. The 33 texts could, in Kilwardby's

belief in the bodily resurrection of the once departed subject (without a theologica exposition on the possible theological correctness of the supposition). It is apparent exposition on the posible theological correctness of the supposition). It is apparent dy commission ositioned themselves not to be understood as hostile to philosophy as such: proposition $40 / 1$ mentioned that a life bound to philosophy must be 'the highest life', whilst 154/2 referred to contemporary (13th-century) philosophers as the 'wise of the world' (sapientes mundi). This strategy again camouflaged the primary target, namely, Aristotelian philosophy that is applied to anything more than pura et vera philosophy; in other words, philosophical applications that deny the crucia early-scholastic differentiation between philosophy and theology and practice philosophy as if it was theology, and vice versa. Tempier did not name any of the Parisian arts magistri by name. However, in the foreword to the 219 propositions, he stated explicitly that ' [...] these condemnations are addressed to people in Paris who study the arts and move beyond the borders of their faculty'. Of course, that could only refer to the arts magistri and their students. Indeed, Tempier repeatedly referred back to Aquinas' counsel in De unitate against arts magistri who 'dwell in the ical issues' and 'say things which are true in philosopy , but then set it up theolog aquinst Catholic teachings as coninas was being quoted in condemned on several points in the 219 propositions as well. Aquinas passed away before the events of Mager and Boethius of Dacia had to experience firsthand, namely, to be excommunicated based on intellectual convictions, or otherwise be brought close to excommunication. 
opinion, not further be lectured at Oxford without progressively generating more dogmatic problems (which in effect, nevertheless, implied that the contents of these texts were deemed incommensurable with the standardised teachings of the church, which in turn meant that they were indeed censurable). Whatever was Kilwardby's intention, his timing at Oxford was deeply regrettable if not misguided: the Dominicans would not be able to circumvent an intense and prolonged conflict with the Franciscans about the Oxford condemnations, precisely against the backdrop of the Paris condemnations. The condemnation of the 33 texts at Oxford on 18 March 1277 followed Kilwardby like a shadow for the remainder of his life and irrevocably harmed his reputation as a double magister at Paris and Oxford. The Franciscans would for centuries, even after Aquinas' eventual canonised triumph in 1323 as the 'highest Dominican' and 'most learned scholastic thinker', ride the wave of Kilwardby's 'mistake' - and even the most subtle of all Franciscans, John Duns Scotus (ca. 1266-1308, sobriquet Doctor Subtilis), never was subtle about what was generally perceived as a grave mistake from the highest echelons of the Dominican order.

Only, but a year later, on 12 March 1278, highly probable in terms of a private request from Kilwardby, because of the pressure he experienced henceforth at both Oxford and Canterbury, pope Nicholas III (1225-1280, pope from 1277 to 1280) surprisingly appointed Kilwardby as chancellor. This pope, infamous for his nepotism, provided no reasons why he appointed an English archbishop as chancellor of Porto-Sanctae Rufinae, once the Romans' most important port city. The promotion of chancellors outside national frameworks always was, and in terms of the risks posed by nepotism not without good reason, a sensitive issue in the history of both the papacy and chancellery. The fact that Kilwardby died on 10 September 1279 , just more than a year after this sudden promotion, and was buried with much understatement at the nearby Dominican monastery in Viterbo, whilst his tomb in Canterbury Cathedral, reserved for only archbishops, remained empty, bears unfortunate witness to the ecclesiastical undoing of this once-promising schoolman and impressive double magister at both Paris and Oxford.

The Dominican monastery in Viterbo, similar to so many other Italian monasteries, was destroyed in 1944 during an Allied air offensive. Kilwardby's first and up to this day only biographer (Sommer-Seckendorff 1937:126) has noted in her work, finalised before the destruction of the monastery, with much refinement the Latin inscription on Kilwardby's grave: Venerabilis Fr. Robertus de Kilvarbius; Anglus, Theologus ac Philosophus praeclarus. Archiepiscopus Cantuariensis, Primas Angliae, Cardinalis Portuensis, ordinis Praedicatorum, hic sepultus jacet ('Here lies buried, the venerable Englishman, brother Robert Kilwardby, theologian and most pure philosopher, Archbishop of Canterbury, primate from England, Cardinal of Porto, from the Order of Preachers').

\section{Acknowledgements Competing interests}

The author has declared that no competing interests exist.

\section{Author's contributions}

J.B. is the sole author of this article.

\section{Ethical consideration}

This article followed all ethical standards for a research without direct contact with human or animal subjects

\section{Funding information}

The University of the Free State funded all page- and publication fees.

\section{Data availability statement}

Data sharing is not applicable to this article as no new data were created or analysed in this study.

\section{Disclaimer}

The views and opinions expressed in this article are those of the author and do not necessarily reflect the official policy or position of any affiliated agency of the author.

\section{References}

Aertsen, J.A. \& Endress, G. (eds.), 1999, Averroes and the Aristotelian tradition: Sources, constitution and reception of the philosophy of Ibn Rushd, Brill, Leiden.

Arblaster, J. \& Faesen, R. (eds.), 2014, A companion to John of Ruusbroec, Brill, Leiden.

Ashworth, E.J. 2003, 'Language and logic', in A.S. McGrade (ed.), The Cambridge companion to Medieval philosophy, pp. 73-96, Cambridge University Press, Cambridge.

Belo, C., 2007, Chance and determinism in Avicenna and Averroes, Brill, Leiden.

Bertolacci, A., 2006, The reception of Aristotle's metaphysics in Avicenna's Kita Al-Sifa. A milestone of western metaphysical thought, Brill, Leiden.

Beukes, J., 2011, 'God kan net doen wat God wel doen: Petrus Abelardus se Megariaanse argument in Theologia Scholarium, Opera Theologia III', HTS Teologiese Studies/Theological Studies 67(3), Art. \#883, 1544-1555. https://doi. org/10.4102/hts.v67i1.883

Beukes, J., 2012, 'Vanaf Ockham na kusa: Die ensiklopediese aanspraak van 'n postskolastiek in Middeleeuse filosofie', HTS Teologiese Studies/Theological Studies 68(1), Art. \#2381, 2352-2361. https://doi.org/10.4102/hts.v68i1.1134

Beukes, J., 2018a, 'n Herlesing van Pseudo-Dionisius se metafisika', HTS Teologiese Studies/Theological Studies 74(4), Art. \#5111, 1-9. https://doi.org/10.4102/hts. v74i4.5112

Beukes, J., 2018b, 'Dionisiese spore in Kusa se metafisika', HTS Teologiese Studies/ Theological Studies 74(4), Art. \#5112, 1-8. https://doi.org/10.4102/hts. v74i 4.5112

Beukes, J., 2018c, 'Die Arabiese trajek in die Karolingiese periode in Middeleeuse filosofie', Litnet Akademies 15(3), 502-564.

Beukes, J., 2018d, 'Die Arabiese trajek in die post-Karolingiese periode in Middeleeuse filosofie', Litnet Akademies 15(3), 565-626.

Beukes, J., 2019a, 'Hildegard von Bingen as 'n 12de-eeuse filosoof-teoloog', Litnet Akademies 16(1), pp. 64-102.

Beukes, J., 2019b, “"Maak die wêreld nie tot bespotting nie”: 'n Herwaardering van die filosofiese aspekte in Mechtild von Magdeburg se Das fließende Licht der Gottheit (1250)', Verbum et Ecclesia 40(1), Art. \#1965, 1-8. https://doi.org/10.4102/ ve.v40i1.1965

Beukes, J., 2019c, 'Héloïse d'Argenteuil se filosofiese uitset', HTS Teologiese Studies/ Theological Studies 75(4), Art. \#5281, 1-12. https://doi.org/10.4102/hts.v75i4.5281

Beukes, J., 2019d, 'De potestate regia et papali: 'n "uurglas"-bywerking van die mees onlangse Quidort-navorsing', Litnet Akademies 16(2), 109-168. 
Beukes, J., 2019e, 'Policraticus en Metalogicon: 'n Bywerking van die Saresberiensisnavorsing, 2013-2018', Verbum et Ecclesia 40(1), Art. \#1959, 1-14. https://doi. navorsing, 2013-2018', Ver
org/10.4102/ve.v40i1.1959

Beukes, J., 2019f, “'Foucault se sodomiet”: Damianus se Liber gomorrhianus (1049) heropen', HTS Teologiese Studies/Theological Studies 75(4), Art. \#5216, 1-13. https://doi.org/10.4102/hts.v75i4.5216

Beukes, J., 2020a, Middeleeuse filosofie, Akademia, Pretoria.

Beukes, J., 2020b, "Die "vyf trane" as mistieke uitdrukking in die Dialoë van die Dominikaanse non Katharina van Siena (1347-1380)', Litnet Akademies 17 (in press).

Beukes, J., 2020c, 'Die eliminering van die siel in die filosofiese mistiek van die begyn Marguerite Porete (1250-1310)', Litnet Akademies 17, 1-11.

Beukes, J., 2020d, 'Die triomf van 'n post-skolastieke mistiek oor skolastieke lojalisme: Gersonius versus Ruusbroec (postuum), 1399', HTS Teologiese Studies/Theological Studies 76(1), Art. \#5672. https://doi.org/10.4102/hts.v76i1.5672

Beukes, J., 2020e, " $n$ Nijmegenaar aan die Universiteite van Parys en Heidelberg in die latere Middeleeue: Die lewe en werk van Marsilius van Inghen (ca.1340-1396)', Verbum et Ecclesia 41(1), Art. \#2038, 1-11. https://doi.org/10.4102/ve.v41i1.2038

Beukes, J., 2020f, 'Omnium expetendorum prima est sapientia: Hugo van Saint-Viktor (1097-1141) en die probleem van hiperspesialisasie in die eietydse wetenskapsbegrip', Litnet Akademies 17 (in press).

Beukes, J., 2020g, 'The trinitarian and Christological Minnemystik of the Flemish beguine Hadewijch of Antwerp (fl.1240)', HTS Teologiese Studies/Theological Studies 76(1), Art. \#5865. https://doi.org/10.4102/hts.v76i1.5865

Beukes, J., 2020h, Foucault in Iran, 1978-1979, AOSIS, Cape Town.

Bonner, A., 2007, The art and logic of Ramon Llull, Brill, Leiden.

Bosley, R.N. \& Tweedale, M. (eds.), 2004, Basic issues in Medieval philosophy. Selected readings presenting the interactive discourses among the major figures, Broadview Press, Ontario.

Briggs, C.F. \& Eardley, P.S. (eds.), 2016, A companion to Giles of Rome, Brill, Leiden.

Broadie, A., 2006, 'Robert Kilwardby', in J.J.E. Gracia \& T.B. Noone (eds.), A companion to philosophy in the Middle Ages, pp. 611-615, Blackwell, Oxford.

Brown, S.F., Dewender, T. \& Kobusch, T. (eds.), 2009, Philosophical debates at Paris in the earlier fourteenth century, Brill, Leiden.

Brown, S.F. \& Flores, J.C., 2007, 'Robert Kilwardby', historical dictionary of Medieval philosophy and theology, p. 246, The Scarecrow Press, Plymouth, MA.

Bullough, D.A., 2004, Alcuin: Achievement and reputation, Brill, Leiden.

Canning, J., 1996, A history of Medieval political thought 300-1450, Routledge, London.

Celano, A.J., 1999, 'Robert Kilwardby on the relation of virtue to happiness, Medieval Philosophy and Theology 8(2), 149-162. https://doi.org/10.1017/ S1057060899082031

Celano, A.J., 2013, 'Robert Kilwardby on ethics', in H. Lagerlund \& P. Thom (eds.) A companion to the philosophy of Robert Kilwardby, pp. 315-512, Leiden, Brill.

Colish, M.L., 1999, Medieval foundations of the western intellectual tradition, 400-1400, Yale University Press, New Haven, CT.

Conti, A.D., 2010, 'Realism', in R. Pasnau \& C. Van Dyke (eds.), 2010b, The Cambridge history of Medieval philosophy, Vol. II, pp. 647-660, Cambridge University Press, Cambridge.

Conti, A.D., 2013a, 'Semantics and ontology in Robert Kilwardby's commentaries on the Logica Vetus', in H. Lagerlund \& P. Thom (eds.), A companion to the philosophy of Robert Kilwardby, pp. 65-130, Leiden, Brill.

Conti, A.D. (ed.), 2013b, A companion to Walter Burley. Late Medieval logician and metaphysician, Brill, Leiden.

Copleston, F.C., 1972. A history of Medieval philosophy, Methuen, London.

Copleston, F.C., 1993, A history of philosophy, Volume II, Medieval philosophy, Doubleday, New York.

Corbini, A., 2013, 'Robert Kilwardby and the Aristotelian theory of science', in H. Lagerlund \& P. Thom (eds.), A Companion to the philosophy of Robert Kilwardby pp. 163-208, Brill, Leiden.

Courtenay, W.J., 2008, Ockham and Ockhamism. Studies in the dissemination and impact of his thought, Brill, Leiden.

De Haas, F.A.J., Leunissen, M. \& Martijn, M. (eds.), 2011, Interpreting Aristotle's Posterior Analytics in late antiquity and the Byzantine period, Philosophia Antiqua No. 124, Brill, Leiden.

Donati, S., 2013, 'Robert Kilwardby on matter', in H. Lagerlund \& P. Thom (eds.), A companion to the philosophy of Robert Kilwardby, pp. 239-274, Brill, Leiden.

Dronke, P. (ed.), 1988, A history of twelfth-century western philosophy, Cambridge University Press, Cambridge.

Ebbesen, S., 1998, 'The Paris arts faculty: Siger of Brabant, Boethius of Dacia, Radulphus Brito', in J. Marenbon (ed.), Medieval philosophy. Routledge History of Philosophy, Vol. III, pp. 269-290, Routledge, London.

Evans, G.R. (ed.), 2002, Mediaeval commentaries on the sentences of Peter Lombard Volume I (Vols. II \& III, P.W. Rosemann [ed.], 2010 \& 2015), Brill, Leiden.

Folger-Fonfara, S., 2008, Das 'Super-transzendentale und die Spaltung der Metaphysik: Der Entwurf des Franziskus von Marchia, Brill, Leiden.

Fortenbaugh, W.W., 2006, Aristotle's practical side. On his psychology, ethics, politics and rhetoric, Brill, Leiden.
Friedman, R.L. \& Schabel, C. (eds.), 2006, Francis of Marchia -Theologian and philosopher. A Franciscan at the University of Paris in the early fourteenth century, Brill, Leiden.

Gàl, G., 1953, 'Robert Kilwardby's questions on the metaphysics and physics of Aristotle', Franciscan Studies 13, 7-28.

Gilson, E., 1940, The spirit of mediaeval philosophy, Scribner, New York.

Gracia, J.J.E. \& Noone, T.B. (eds.), 2006, A companion to philosophy in the Middle Ages, Blackwell, Oxford.

Grellard, C. \& Lachaud, F. (eds.), 2015, A companion to John of Salisbury, Brill, Leiden.

Grant, E., 2004, God and reason in the Middle Ages, Cambridge University Press, Cambridge.

Gutas, D. (Intr., ed., comm. \& transl.), 2014, Avicenna and the Aristotelian tradition. Introduction to reading Avicenna's philosophical works, Brill, Leiden.

Hammond, J.M., Hellmann. J.A.W. \& Goff, J. (eds.), 2014, A companion to Bonaventure, Brill, Leiden.

Hannam, J., 2009, God's philosophers: How the Medieval world laid the foundations of modern science, Icon Books, London.

Haren, M., 1985, Medieval thought. The western intellectual tradition from antiquity to the thirteenth century, Macmillan, London.

Hoenen, M.J.F.M. \& Bakker, P.J.J.M. (eds.), 2000, Philosophie und theologie des ausgehenden Mittelalters. Marsilius von Inghen und das Denken seiner Zeit, Brill, Leiden.

Hyman, A., Walsh, J.J. \& Williams, T. (eds.), 2010, Philosophy in the Middle Ages: The Christian, Islamic and Jewish traditions, Hackett, Indianapolis, IN.

Kenny, A., 2005, Medieval philosophy, Clarendon Press, Oxford.

Kilwardby, R., 1976, De ortu scientiarum, A.G. Judy (ed.), Oxford University Press for the British Academy, Oxford.

Kilwardby, R., 1982-1995, Quaestiones in libros Sententiarum, J. Schneider, E. Gösmann, G. Leibold \& R. Schenk (eds.), Verlag der Bayerischen Akademie der Wissenschaften, Munich.

Kilwardby, R., 1987, De tempore. De spiritu fantastico, O. Lewry (ed.), Oxford University Press for the British Academy, Oxford.

Kilwardby, R., 1993, 'On time. Imagination', in A. Broadie (ed., intr. \& transl.), On time. Imagination. Introduction and translation, pp. 376-383, Oxford University Press for the British Academy, Oxford.

Kirchhoff, R., 2008, Die Syncategoremata des Willhelm von Sherwood. Kommentierung und historische Einordnung, Brill, Leiden.

Klein-Braslavy, S., 2011, 'Without any doubt'. Gersonides on method and knowledge, Brill, Leiden.

Kneepkens, C.H., 2013, 'Robert Kilwardby on grammar', in H. Lagerlund \& P. Thom (eds.), A companion to the philosophy of Robert Kilwardby, pp. 17-64, Brill, Leiden.

Koterski, J.W., 2009, An introduction to Medieval philosophy: Basic concepts, WileyBlackwell, Sussex.

Kretzmann, N., Kenny, A. \& Pinborg, J. (eds.), 1982, The Cambridge history of later Medieval philosophy, Cambridge University Press, Cambridge.

Lagerlund, H. (ed.), 2011, Encyclopedia of Medieval philosophy. Philosophy between 500 and 1500 , Springer, London.

Lagerlund, H. \& Thom, P., 2013, 'Introduction: The life and philosophical works of Robert Kilwardby', in H. Lagerlund \& P. Thom (eds.), A companion to the philosophy of Robert Kilwardby, pp. 1-16, Brill, Leiden.

Levy, I.C. (ed.), 2006, A companion to John Wyclif: Late Medieval theologian, Brill, Leiden.

Lewry, O., 1981, 'Robert Kilwardby on meaning', in J.P. Beckmann (ed.), Sprache und Erkenntnis im Mittelalter, pp. 376-383, Walter de Gruyter, Berlin.

Lewry, O., 1983, 'Robert Kilwardby on imagination: The reconciliation of Aristotle and Augustine', Medioevo IX, 1-42.

Luscombe, D.E., 1997, Medieval thought, Opus-Oxford University Press, Oxford.

Luscombe, D.E., 2010, 'Monks and friars', in R. Pasnau \& C. Van Dyke (eds.), The Cambridge history of Medieval philosophy, Vol. I, pp. 63-75, Cambridge University Press, Cambridge.

Maierù, A., 2013., 'Robert Kilwardby on the division of the sciences', in H. Lagerlund \& P. Thom (eds.), A companion to the philosophy of Robert Kilwardby, pp. 353-390, Brill, Leiden.

Marenbon, J., 1991, Later Medieval philosophy (1150-1350): An introduction, Routledge, London.

Marenbon, J. (ed.), 1998, Medieval philosophy: Routledge history of philosophy, Vol. III, Routledge, London.

Marenbon, J., 2007, Medieval philosophy: An historical and philosophical introduction, Routledge, London.

Marenbon, J. \& Luscombe, D.E., 2003, 'Two Medieval ideas: Eternity and hierarchy', in A.S. McGrade (ed.), The Cambridge companion to Medieval philosophy, pp. 51-72, Cambridge University Press, Cambridge.

Martin, C.J.F., 1996, An introduction to Medieval philosophy, Edinburgh University Press, Edinburgh.

McAleer, G.J., 1999, 'The presence of Averroes in the natural philosophy of Robert Kilwardby', Archiv für Geschichte der Philosophie 81(1), 33-54. https://doi. org/10.1515/agph.1999.81.1.33 
McGinnis, J. \& Reisman, D.C. (eds.), 2004, Interpreting Avicenna: Science and philosophy in Medieval Islam, Brill, Leiden.

McGrade, A.S. (ed.), 2003, The Cambridge companion to Medieval philosophy, Cambridge University Press, Cambridge.

McGuire, B.P. (ed.), 2006, A companion to Jean Gerson, Brill, Leiden.

McGuire, B.P. (ed.), 2011, A companion to Bernard of Clairvaux, Brill, Leiden

Palmén, R., 2014, Richard of St Victor's theory of imagination, Brill, Leiden.

Pascoe, L.B., 2005, Church and reform. Bishops, theologians, and canon lawyers in the thought of Pierre d'Ailly, Brill, Leiden.

Pasnau, R., 2003, 'Human nature', in A.S. McGrade (ed.), The Cambridge companion to Medieval philosophy, pp. 208-230, Cambridge University Press, Cambridge.

Pasnau, R. \& Van Dyke, C. (eds.), 2010a, The Cambridge history of Medieval philosophy, Vol. I, Cambridge University Press, Cambridge.

Pasnau, R. \& Van Dyke, C. (eds.), 2010b, The Cambridge history of Medieval philosophy, Vol. II, Cambridge University Press, Cambridge.

Pelletier, J.E., 2013, William Ockham on metaphysics.The science of being and God Brill, Leiden.

Pickavé, M., 2007, Heinrich von Gent über Metaphysik als erste Wissenschaft, Brill, Leiden.

Putallaz, F.X., 2010, 'Censorship', in R. Pasnau \& C. Van Dyke (eds.), The Cambridge history of Medieval philosophy, Vol. I, pp. 99-113, Cambridge University Press, Cambridge.

Read, S., 2010, 'Inferences', in R. Pasnau \& C. Van Dyke (eds.), The Cambridge history of Medieval philosophy, Vol. I, pp. 173-184, Cambridge University Press, Cambridge.

Reisman, D.C., 2002, The making of the Avicennan tradition, Brill, Leiden.

Resnick, I.M. (ed.), 2013, A companion to Albert the Great. Theology, philosophy and the sciences, Brill, Leiden.

Rosemann, P.W. (ed.), 2010, Mediaeval commentaries on the sentences of Peter Lombard, Vol. II, Brill, Leiden.

Rosemann, P.W. (ed.), 2015, Mediaeval commentaries on the sentences of Peter Lombard, Vol. III, Brill, Leiden.

Rosenthal, F., 2007, Knowledge triumphant. The concept of knowledge in Medieval Islam, Brill, Leiden.

Rosier-Catach, I., 2010, 'Grammar', in R. Pasnau \& C. Van Dyke (eds.), The Cambridge history of Medieval philosophy, Vol. I, pp. 196-218, Cambridge University Press, Cambridge.

Schabel, C. (ed.), 2006, Theological Quodlibeta in the Middle Ages: The thirteenth century, Brill, Leiden.
Schabel, C. (ed.), 2007, Theological Quodlibeta in the Middle Ages: The fourteenth century, Brill, Leiden.

Schweid, E., 2008, The classic Jewish philosophers. From Saadia through the Renaissance, Brill, Leiden.

Silva, J.F., 2011, 'Robert Kilwardby', in H. Lagerlund (ed.), Encyclopedia of Medieva philosophy - Philosophy between 500 and 1500, pp. 1148-1153, Springer, London.

Silva, J.F., 2012, Robert Kilwardby on the human soul, Brill, Leiden.

Silva, J.F., 2013, 'Robert Kilwardby on the theory of the soul and epistemology', in H. Lagerlund \& P. Thom (eds.), A companion to the philosophy of Robert Kilwardby, pp. 275-314, Brill, Leiden.

Šmahel, F. (ed.), 2007, Die Prager Universität im Mittelalter, Brill, Leiden.

Sommer-Seckendorff, E.M.F., 1937, Studies in the life of Robert Kilwardby, O.P., Sabinae, Rome.

Suto, T., 2012, Boethius on mind, grammar and logic, Brill, Leiden.

Syros, V., 2007, Die Rezeption der aristotelischen politischen philosophie bei Marsilius von Padua. Eine untersuchung zur ersten Diktion des Defensor pacis, Brill, Leiden.

Terry, W.R. \& Stauffer, R. (eds.), 2017, A companion to Marguerite Porete and the mirror of simple souls, Brill, Leiden.

Thijssen, J.M.M.H. \& Zupko, J. (eds.), 2001, The metaphysics and natural philosophy of John Buridan, Brill, Leiden.

Thom, P., 2007, Logic and ontology in the syllogystic of Robert Kilwardby, Brill, Leiden.

Thom, P., 2013, 'Robert Kilwardby on the syllogystic form', in H. Lagerlund \& P. Thom (eds.), A companion to the philosophy of Robert Kilwardby, pp. 131-162, Brill, Leiden.

Toivanen, J., 2013, Perception and the internal senses: Peter of John Olivi on the cognitive functions of the sensitive soul, Brill, Leiden.

Treschow, M., Otten, W. \& Hannam, W. (eds.) 2007, Divine creation in ancient, Medieval and early modern thought, Brill, Leiden.

Trifogli, C., 2013, 'Robert Kilwardby on time', in H. Lagerlund \& P. Thom (eds.) A companion to the philosophy of Robert Kilwardby, pp. 209-238, Brill, Leiden.

Wagner, M.F., 2008, The enigmatic reality of time. Aristotle, Plotinus, and today, Brill, Leiden.

Walzer, R., 1967, 'Islamic and Greek philosophy: Al-Kindi and ar-Razi; al-Farabi and his successors' in A.H. Armstrong (ed ) The Cambridge history of later Greek and early Medieval philosophy, pp. 643-652, Cambridge University Press, Cambridge.

Warnar, G., 2007, Ruusbroec. Literature and mysticism in the fourteenth century, Brill, Leiden.

Wilson, G.A. (ed.), 2011, A companion to Henry of Ghent, Brill, Leiden.

Wood, J., 2012, The politics of identity in Visigothic Spain. Religion and power in the histories of Isidore of Seville, Brill, Leiden. 